\title{
Pleistocene speleothem fracturing in the foreland of the Western Carpathians: a case study from the seismically active eastern margin of the Bohemian Massif
}

\author{
Ondřej BÁBEK ${ }^{1, ~ *}$, Miloš BRIESTENSKÝ², Gabriela PŘECECHTĚLOVÁ ${ }^{1}$, Petra ŠTĚPANČíKOVÁ², \\ John C. HELLSTROM ${ }^{3}$ and Russell Neil DRYSDALE ${ }^{4}$ \\ 1 Palacký University of Olomouc, Department of Geology, 17 listopadu 12, 77146 Olomouc, Czech Republic \\ 2 Academy of Sciences of the Czech Republic, Institute of Rock Structure and Mechanics, v.v.i., V Holešovičkách 41, \\ Prague 8182 09, Czech Republic \\ 3 University of Melbourne, Department of Resource Management and Geography, Melbourne, Vic 3010, Australia \\ 4 University of Melbourne, School of Earth Sciences, Melbourne, Vic 3010, Australia
}

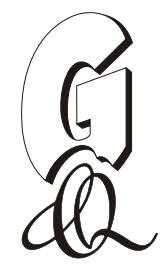

Bábek, O., Briestenský, M., Přecechtělová, G., Štěpančíková, P., Hellstrom, J.C., Drysdale, R.N., 2015. Pleistocene speleothem fracturing in the foreland of the Western Carpathians: a case study from the seismically active eastern margin of the Bohemian Massif. Geological Quarterly, 59 (3): 491-506, doi: 10.7306/gq.1225

\begin{abstract}
We studied speleothem-fracturing styles and their tectonic context in three cave systems situated in the eastern Bohemian Massif, close to the Western Carpathians orogenic front: the Za hájovnou, Javoříčko, and Mladeč caves. The morphology of the speleothems in particularly thin stalactites, and supporting evidence from the cave interior, indicates a tectonic origin of the breakage. U/Th series dating of the stalactites, supported by Optically Stimulated Luminiscence $(\mathrm{OSL})$ and ${ }^{14} \mathrm{C}$ dating of soft sediments indicate that most of the fracturing occurred in the Upper Pleistocene, with the last fracturing events corresponding to MIS6 and MIS5 stages. OSL dating of faulted soft-sediment infill may even indicate that latest Pleistocene to Early Holocene tectonic events occurred in the Mladeč Cave. The speleothem fracturing is discussed in the regional context of the seismically active Nysa-Morava Zone situated at the junction between the Bohemian Massif (Elbe Fault Zone) and the Western Carpathians. This study provides the first evidence of palaeoseismicity from the subsurface and the oldest dated palaeoseismicity from the contact between the Western Carpathians and the Bohemian Massif.
\end{abstract}

Key words; Speleothems, U/Th series dating, palaeoseismicity, Pleistocene, Bohemian Massif, Western Carpathians.

\section{INTRODUCTION}

Cenozoic to present-day brittle deformation accompanied by faulting, volcanic activity, present-day seismicity, subsidence in grabens, and related geomorphic phenomena characterize the orogenic foreland of the European Alpine-Western Carpathians chain. Most distinct are the graben-like structures of the European Cenozoic Rift System (ECRIS), in particular the Upper Rhine, Bresse, Limagne and Eger Grabens (Prodehl et al., 1995; Dèzes et al., 2004; Wilson and Downes, 2006). In addition, a non-negligible part of the foreland deformation relates to old fault systems, which were rejuvenated during the Late Cenozoic plate convergence between the AlpineCarpathian orogenic belt and its European Platform foreland (Jarosiński et al., 2009; Špaček et al., 2011; Widera and Hałuszczak, 2011). The Nysa-Morava Zone (NMZ) is one of these regions, characterized by slow, present-day brittle deformation, developed at the contact between the eastern Bohemian Mas-

\footnotetext{
* Corresponding author, e-mail: babek@prfnw.upol.cz Received: January 13, 2015; accepted: March 6, 2015; first published online: March 26, 2015
}

sif and the Western Carpathians since the Miocene. The NMZ is characterized by present-day low-magnitude seismicity, evidence of palaeoseismic events, horst-and-graben structures, linear sedimentary basins filled with up to $300 \mathrm{~m}$ thick Pliocene to Holocene continental deposits, Pliocene to Pleistocene alkali basic volcanic rocks, and present-day $\mathrm{CO}_{2}$ fluxes (Špaček et al., 2011, 2015).

Much of the evidence for palaeoseismic events may be destroyed by erosion and the deposition of colluvial and alluvial sediments. However, a strong record of pre-historic seismicity can be preserved in caves, which are sheltered from surface processes. Palaeoseismic indicators in caves include faulting in soft cave sediments and, in particular, speleothem fracturing and destruction (Gilli et al., 1999; Becker et al., 2006; Šebela, 2008; Panno et al., 2009; Audemard et al., 2011). There is a wide range of palaeoseismic information locked in the broken speleothems. Their growth patterns can be used for relative dating of co-seismic fracturing (Gilli, 2005). Speleothems fallen during seismic events can be interpreted as natural pendulums, which may provide information about the direction and mechanical properties of seismic ground motion (Postpischl et al., 1991; Gilli et al., 1999). Palaeomagnetic and U-series dating of broken speleothems can provide information about the timing of seismic events (Morinaga et al., 1994; Pons-Branchu et al., 
2004; Kagan et al., 2005; Plan et al., 2010). In addition to past earthquakes, even the present-day fault displacement and speleothem destruction can be monitored in real time using extensometers (Kashima, 1993; Gilli, 2005; Briestenský et al., 2010). On the other hand, there is ongoing debate about the aseismic causes of speleothem breakage, such as the human presence in caves, shocks due to mine blasting, cryogenic fracturing, gravitational collapse, and catastrophic floods (Crispim, 1999; Gilli, 2005; Frumkin et al., 2009; Becker et al., 2012; Lundberg and McFarlane, 2012). Despite the controversy, it is sometimes possible to eliminate aseismic fracturing by careful observation of speleothem morphology and accompanying evidence such as the study of soda-straws, which are regarded as reliable indicators of co-seismic fracturing (Gilli et al., 1999; Becker et al., 2006), and/or by selecting caves untouched by past human activity.

In this paper, we present the results of speleothem fracturing from several newly discovered cave corridors in the seismically active NMZ in the foreland of the Western Carpathians orogen. The seismogenic origin of the fracturing is discussed based on the morphology of thin stalactites and soda-straws and their $\mathrm{U} / \mathrm{Th}$ series dating. They occur in cave corridors, the morphology of which is controlled by cleavage and fracture systems suggesting that they developed in specific stress fields, which are discussed against the background of the regional stress field in the NMZ. The aim of this paper is to discuss the speleothem breakage and the associated tectonic features as important proxies of Late Quaternary palaeoseismicity at the contact between the Bohemian Massif and the Western Carpathians.

\section{GEOLOGICAL SETTING}

The study area is located in the eastern Czech Republic, NW of the city of Olomouc (Fig. 1). Geologically, this region is situated on the northeastern margin of the Bohemian Massif, close to its contact with the Western Carpathians orogenic belt.

The bedrock geology was shaped by the Variscan orogenic cycle and by post-Variscan sedimentation, uplift, volcanism, and brittle deformation along rejuvenated faults (Kalvoda et al., 2008; Śpaček et al., 2011). The oldest rocks in the area are Neoproterozoic igneous and medium-grade metamorphic rocks (the Brunovistulian terrane), which are overlain by Lower Devonian to Upper Tournaisian siliciclastic and carbonate sedimentary rocks and basic volcanic rocks of the Moravo-Silesian Zone (Bábek et al, 2007; Kalvoda et al., 2008). These successions pass upwards into several kilometres thick sequences of Visean deep-marine siliciclastics of the Moravo-Silesian Culm Basin and the overlying coal-bearing continental and paralic successions of the Upper Silesia Basin. They were deposited in a deep marine to continental foreland basin (Hartley and Otava, 2001; Bábek et al., 2004), and recorded the final stages of the Variscan plate convergence between the Lugodanubian and Brunovistulian terranes (e.g., Franke and elaźniewicz, 2000; Schulmann and Gayer, 2000; Mazur et al., 2006). Following a long period of uplift, sedimentation in the area renewed in the Early Miocene, when the southern limits of the region were flooded by the linear marine basin of the Carpathian Foredeep. The Carpathian Foredeep is a foreland basin whose evolution relates to the latest
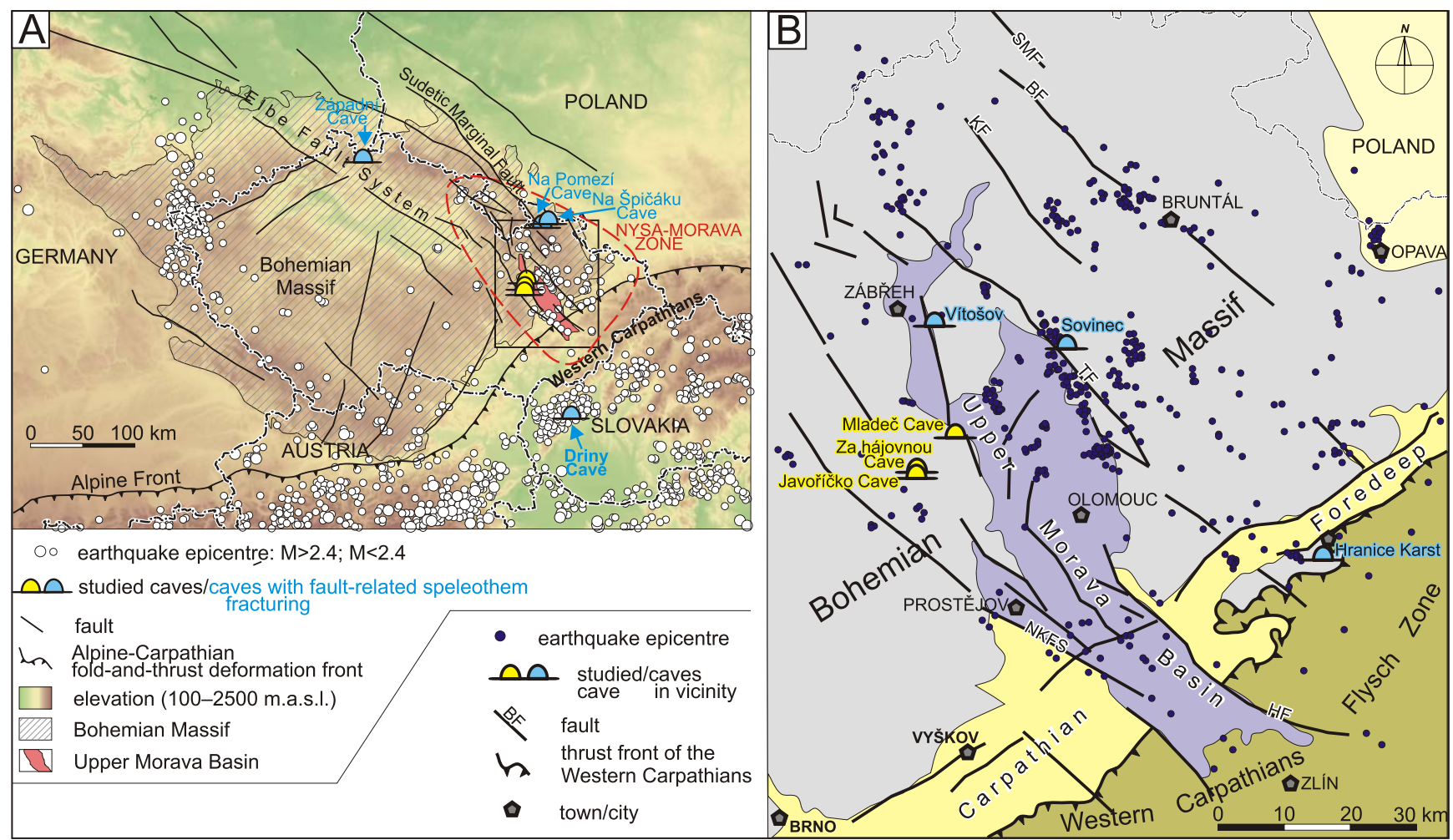

Fig. 1. Location of the area studied in the central European context at the contact between the Elbe Fault Zone and the Western Carpathians

A - the map of which the earthquake epicentres are adopted is from Institute of Physics of the Earth, Masaryk University Brno, IPE 2009 catalogue [2000-2009, $M_{L} \geq 0.5$, Špaček et al. (2015)]; B - important regional faults: BF - Bělá Fault, HF - Holešov Fault, KF - Klepáčov Fault, NKFS - Nectava-Konice-Kvasice, SMF - Sudetic Marginal Fault, TF - Temenice Fault 
Oligocene to Late Miocene thrusting and stacking of nappes in the Flysch Zone of the Outer Western Carpathians (Stráník et al., 1993; Picha et al., 2006). Following basin inversion in the Late Miocene, the present-day structure of the Carpathian Foredeep is largely controlled by deep-seated ENE-WSW trending faults. In Late Miocene times, marine sedimentation ceased in the study area, giving way to Pliocene to Holocene lacustrine and fluvial sedimentation (Růžička et al., 1973) in a system of NW-SE trending linear basins of the Nysa-Morava Zone (Fig. 1). These basins are filled by a more than $300 \mathrm{~m}$ thick succession of continental deposits, Pliocene to Holocene in age. The biggest of the linear basins, the Upper Morava Ba$\mathrm{sin}$, is a $90 \mathrm{~km}$ long and $25 \mathrm{~km}$ wide trough, trending perpendicular to the Carpathian Foredeep. The basins are bound to adjacent elevations by normal faults, forming a horst-andgraben structure reflected in a prominent surface morphology as well as in gravity anomaly patterns (Grygar and Jelínek, 2003; Špaček et al., 2011).

The regional strike and alignment of major lithological units of Devonian to Late Carboniferous age typically show NNE to SSW trends in the Variscan structural level, consistent with the trends of bedding planes and cleavage on a smaller scale (Grygar and Vavro, 1995; Bábek et al., 2006). The cleavage is most prominent and penetrative in the NW and tends to fade out towards the SE. The Variscan structures are crosscut by numerous fractures, generally trending NW to SE, which represent the SE extension of the upper Elbe (= Labe River) Fault System. This major wrench zone was already active during the Variscan orogeny (Rajlich, 1990; Aleksandrowski, 1995; Scheck et al., 2002). The Meso-Cenozoic movements on the upper Elbe Fault System resulted in a block structure, which largely controlled sedimentation patterns at the northeastern margin of the Bohemian Massif (Špaček et al., 2015). The NMZ hosts several prominent, seismically active faults, the Bělá, Klepáčov, Temenice, Holešov faults, and the Nectava-Konice-Kvasice (Fig. 1). Delimited by the NW-SE trending fault system, the NMZ is characterized by Oligocene to Pleistocene volcanic activity, historical and present-day seismicity, and increased $\mathrm{CO}_{2}$ fluxes (Ulrych et al., 2013; Spaček et al., 2015).

The stress release on the NMZ faults is relatively wellknown from present-day earthquakes (the strongest instrumentally-recorded event from 1986 had the magnitude $M_{L} \approx 3.8$ ) as well as from historical data (1562 earthquake near Kłodzko, $\mathrm{M}_{w}$ $\approx 4.9\left[\mathrm{I}_{\mathrm{EMS}}=7\right] ; 1901$ event near Trutnov. $\left.\mathrm{M}_{\mathrm{w}} \approx 4.7\left[\mathrm{I}_{\mathrm{MSK}}=7\right]\right)$ (Guterch and Lewandowska-Marciniak, 2002). However, there is only limited knowledge of pre-historical seismicity and its spatial distribution. Based on its structure and geometry along with the focal mechanisms of present-day seismic events, the NMZ is interpreted as a prominent NW-SE trending zone, which developed in a dextral transpressional setting by tectonic rejuvenation of mutually-intersecting Variscan and post-Variscan fault systems during the final stages of thrust stacking and emplacement of the Western Carpathians fold-and-thrust belt. The dextral transpression gave rise to a rhombic shape of the main Plio-Quaternary depocentres, which are supposed to have subsided in a pull-apart regime (Špaček et al., 2015).

\section{CAVE SYSTEMS STUDIED}

The Upper Morava Basin and in particular the adjacent uplands and horsts host several minor karst areas with a number of small cave systems (Table 1 and Fig. 1). While the age of karstification and the origin of the caves is a matter of debate and may have well-continued from Mesozoic up to the present day (Otava and Morávek, 2013), their infill is relatively welldated in several cave examples.

Three relatively large cave systems of the Javořičko and Mladeč Karst areas are addressed in this study: the Za hájovnou (JZH) Cave, Javoříčko Cave, Mladeč Cave, and three smaller caves situated near the Mladeč Cave. The JZH Cave is an approximately $500 \mathrm{~m}$ long cave system with abundant finds of Middle Pleistocene (Holsteinian) mammals situated near its entrance (Musil, 2005). Various parts of the cave have been dated by U/Th dating of flowstones to $118 \pm 1$ to $267 \pm 3$ ka and by magnetostratigraphy to the Brunhes-Matuyama boundary (oldest datum from the cave infill; Musil, 2005; Kadlec et al., 2005; Lundberg et al., 2014). In 2012, new corridors were discovered in this cave with abundant findings of broken speleothems previously untouched by human activity. The new corridors were documented and sampled in late 2012 and early 2013. The Mladeč Cave is an example of a well-dated and well-documented cave system, with Upper Paleolithic (Aurignacian) settlements dated by a wealth of human artefacts and ${ }^{14} \mathrm{C}$ dating to $30,960 \pm 140$ to $39,970 \pm 680 \mathrm{yr}$ calBP (Svoboda et al., 2002; Wild et al., 2006). The Javoříčko Cave is located about $550 \mathrm{~m}$ NNE of the JZH Cave entrance and it the largest cave system in the study area with a total corridor length of more than $5 \mathrm{~km}$, developed at three storeys. Cryogenic cave calcite was discovered at shallow depths below the surface in the Javořičko Cave, which have been dated to $37.84 \pm 0.73 \mathrm{ka}, 38.09 \pm$ $0.60 \mathrm{ka}$, and $34.60 \pm 0.41 \mathrm{ka}$ (Žák et al., 2011).

\section{MATERIAL AND METHODS}

Structural analysis of the JZH, Mladeč, and Javořičko caves was based on detailed cave-corridor mapping and on orientation analysis of small-scale structures (cleavage, bedding planes, fractures, and faults with striations) in the bedrock as well as in the soft sediment infill. The same orientation analysis

Karst areas near the Upper Morava Basin

\begin{tabular}{|l|c|c|c|c|}
\hline \multicolumn{1}{|c|}{ Name } & $\begin{array}{c}\text { Number } \\
\text { of caves }\end{array}$ & $\begin{array}{c}\text { Total length of cave } \\
\text { corridors [m] }\end{array}$ & Longest cave (length) & Bedrock geology \\
\hline Vítošov area & 1 & $\sim 15$ & unnamed $(15 \mathrm{~m})$ & $\begin{array}{c}\text { Middle Devonian crystalline carbonates, } \\
\text { low-grade metamorphism }\end{array}$ \\
\hline Sovinec area & 3 & $\sim 170$ & Sovinecká Cave $(96 \mathrm{~m})$ & $\begin{array}{c}\text { Devonian-Carboniferous carbonates, } \\
\text { low-grade metamorphism }\end{array}$ \\
\hline Hranice Karst & 16 & $\sim 1400$ & Zbrašov Cave $(930 \mathrm{~m})$ & Middle Devonian-Lower Carboniferous carbonates \\
\hline Javoříčko Karst & 34 & $\sim 6050$ & Javoříčko Cave $(5250 \mathrm{~m})$ & Middle Devonian-Lower Carboniferous carbonates \\
\hline Mladeč Karst & 8 & $\sim 1500$ & Mladeč Cave $(1080 \mathrm{~m})$ & Middle-Upper Devonian carbonates \\
\hline
\end{tabular}


was done on the surface in the broader vicinity of the caves. The subsurface architecture of cave corridors in the JZH Cave was studied using electrical resistivity tomography (ERT). Six ERT profiles, 62 and $117 \mathrm{~m}$ long with 2 and 3 m electrode-spacing, were measured using the automatic geoelectrical system ARES (GF Instruments, Czech Republic). The WennerSchlumberger method, with 32 electrodes in a single array, was used. The longest section was measured using the roll-along method with an eight-electrode increment. The stacking of four pulses with a 0.5-s pulse time was used at each measurement point. The maximum depth of the apparent resistivity pseudosection was $\sim 18 \mathrm{~m}$. An inverse model resistivity section was produced from the apparent resistivity pseudosection by the least-square inversion method using RES2DINV software (Geotomo Software, Malaysia).

The distribution of speleothem fracturing was mapped in each of the cave systems. Nine sampling points on three broken stalactites from the JZH Cave were uranium-series-dated by multi-collector inductively-coupled plasma mass spectrometry according to the analytical protocols described by Hellstrom (2003). The initial ${ }^{230} \mathrm{Th} /{ }^{232} \mathrm{Th}_{\mathrm{A}}$ ratio was applied to the $\mathrm{U}$ and $\mathrm{Th}$ results from the speleothem to correct for contributions from detrital ${ }^{230}$ Th (Hellstrom, 2006). Selected charcoal samples from the soft sediment fill of the Mladeč Cave were dated by ${ }^{14} \mathrm{C}$ series by CAIS 0.5 MeV accelerator mass spectrometer (AMS) at the Center for Applied Isotope Studies of the University of Georgia, USA. The ${ }^{14} \mathrm{C}$ ages were calibrated to calendar ages using the calibration curve of Fairbanks et al. (2005). Optically-stimulated luminiscence (OSL) dating was performed on three samples from soft sediments of the Mladec Cave. The OSL analyses were performed at the Luminescence Dating Laboratory of the Institute of Physics, Silesian University of Technology, Poland, using a germanium spectrometer and the OSL-SAR single aliquot regenerative method on quartz grains.

\section{RESULTS}

\section{TECTONIC STRUCTURES IN THE HOST ROCK}

A study of cave interiors and surface outcrops near the caves revealed a distinct structural fabric of the carbonate rocks that hosted the cave systems. The carbonate rocks are massive to thick-bedded, partly-recrystallised biodetrital calcarenites and calcirudites with abundant crinoids, platy stromatoporoids, corals, and bryozoans. The most prominent structures include minor folds, developed in well-bedded varieties of the limestone, and cleavage, well-visible in massive or thick-bedded varieties of the carbonate rock. The cleavage is penetrative and emphasized by microscopic banding of the limestone, the preferential growth of recrystallised sparry calcite, and the effects of ductile shearing and rotation of intraclasts and fossils (crinoid ossicles, stromatoporoids). The cleavage planes bear distinct stretching lineation, parallel to the fold axes. The mean strike of the cleavage and the axial planes of the folds is NNE-SSW, dipping towards the WNW (Fig. 2), which is the principal direction of the cave corridors in the JZH Cave. Pressure shadows around the crinoid ossicles show signs of rotation, indicating a NNE-SSW-directed, strike-slip dextral shear along the cleavage planes. Fracturing of the host rock manifests itself in three distinct sets of subvertical joints trending, respectively, in the WNW-ESE, W-E, and NW-SE directions (Fig. 2). Joints of the first set are roughly perpendicular to the cleavage and they are extensional in origin. The latter two joint systems are probably of shear origin. The spatial relationships between the extensional and shear joints suggest that they might have formed in a single stress field.

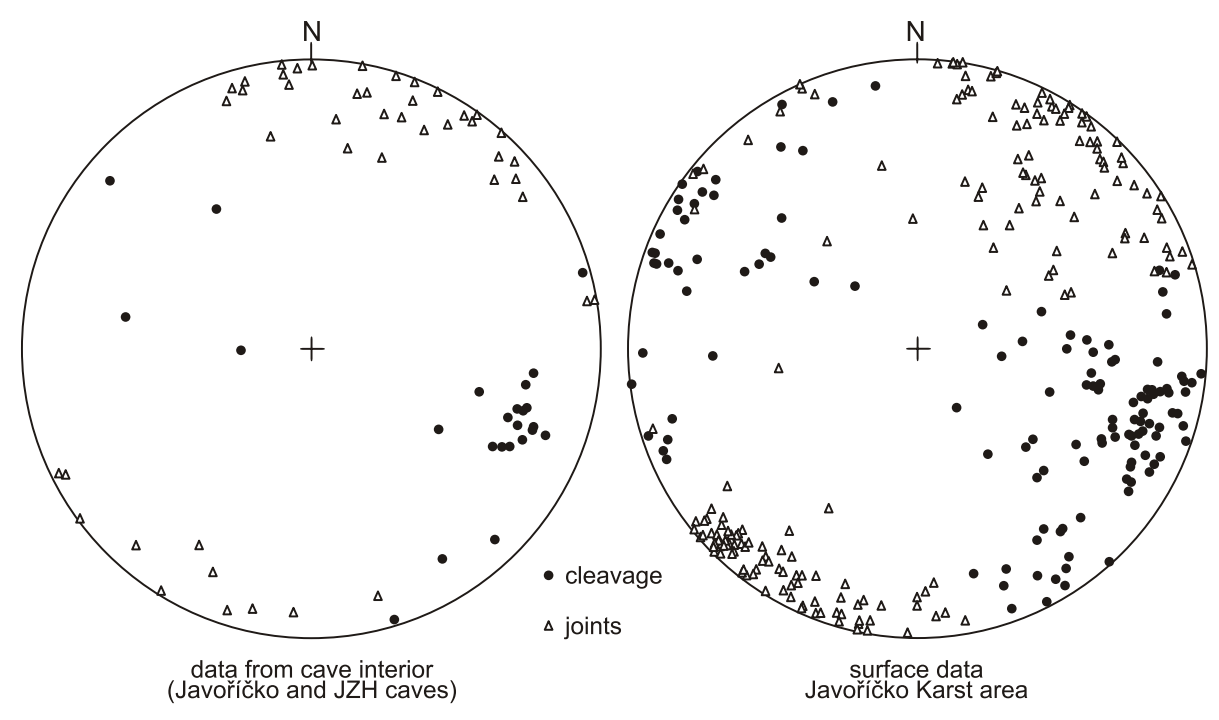

Fig. 2. Stereoplots of mesoscopic tectonic structures (joints, cleavage) from the Javoříčko and JZH caves (left) and from surface exposures in the vicinity of the caves (right) 


\section{MORPHOLOGY OF CAVE PASSAGES}

The JZH Cave and the Javoříčko Cave both create a network of linear corridors running in two principal directions, nearly perpendicular to one another (Fig. 3). The first corridor system, running in a NNE-SSW direction, includes for example the Olomouc Hall, the Corridor of Peace, the Brezina Corridor and the Crystal Corridor in the Javoríčko Cave system, the Birthday Corridor, and the Easter Corridor in the JZH Cave system. The second corridor system, running in a WNW-ESE direction, roughly perpendicular to the first one, includes e.g., the Discovery Corridor and the Hall of Giants in the Javoŕícko Cave. Cross-sections of many of these corridors are strongly elongated, subvertical or steeply inclined. The inclined, NNE-SSW trending corridors generally dip towards the WNW. Corridors in the Mladeč Cave run predominantly in the NW-SE (Virgin Corridor) and NE-SW (Hall of the Dead) directions (Fig. 4).

Six ERT sections, 62 to $117 \mathrm{~m}$ long, were measured on the surface, above the JZH Cave system (Fig. 5). The resistivity values are grouped into three distinct domains. The high-resistivity domains ( 1,300 to $26,112 \Omega . \mathrm{m})$ are voluminous and tend to be located in the lower parts of the sections. Consistent with the local geology, they are interpreted as massive limestone. The low-resistivity domains (27.6 to $\sim 210 \Omega$.m) occur near the surface or in subvertical zones, which are interpreted as clayand silt-rich soil cover and/or infill of cave corridors and fissures. The medium-resistivity domains ( 210 to 1,300 $\Omega$.m) occur in subvertical zones, which we interpret as fractured and karstified limestone. Most of the geophysically-documented karstification occurs along planar zones, which coincide with several cave corridors in ground plan. Orientation of these zones corresponds to the subvertical, WNW-dipping, NNE-SSW trending cleavage and ESE-WNW trending fractures and faults in the underlying rocks (see below). Most of the speleothem fracturing is associated with the cleavage (Fig. 3).

\section{FAULT TECTONICS OF CAVE INTERIORS}

Apart from the peculiar mesh-like shape of the corridors, which indicates a strong tectonic control on the cave morphology, many of the corridor walls show signs of faulting and brittle deformation that clearly postdate the main processes of karstification. The predominant system of faults in the Javořičko and JZH is subvertical, NNE-SSW trending, and dipping
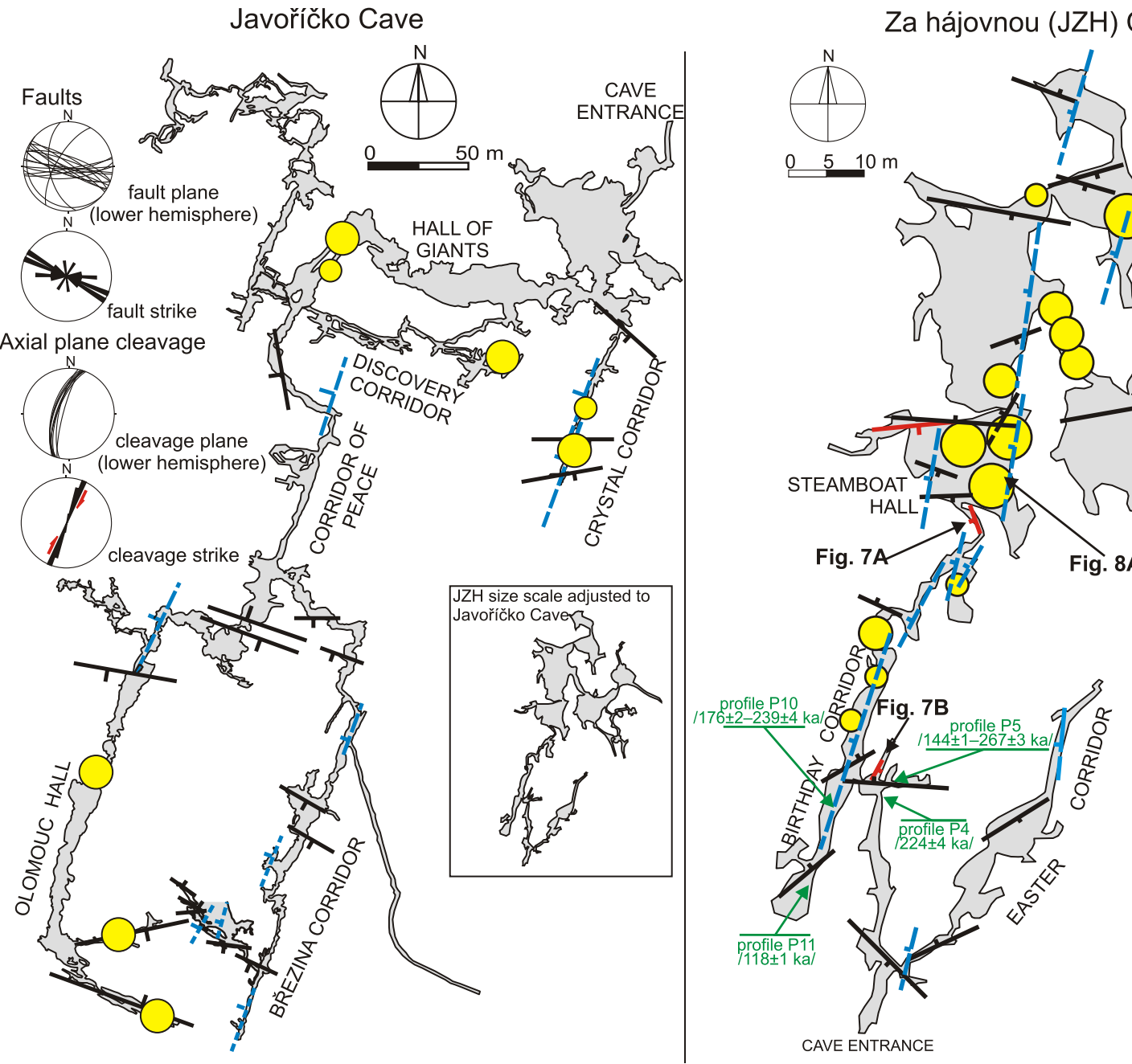

Cave 


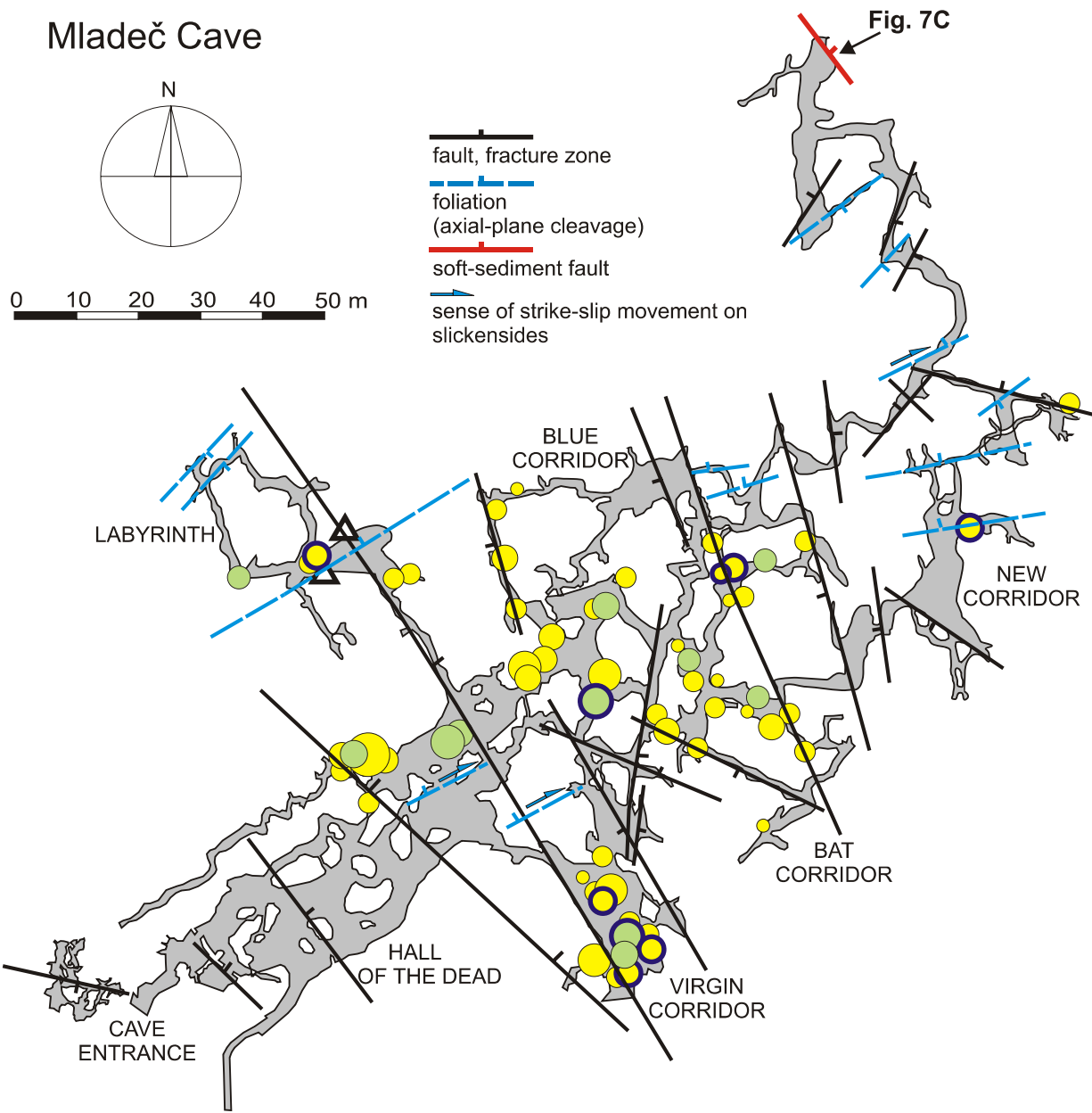

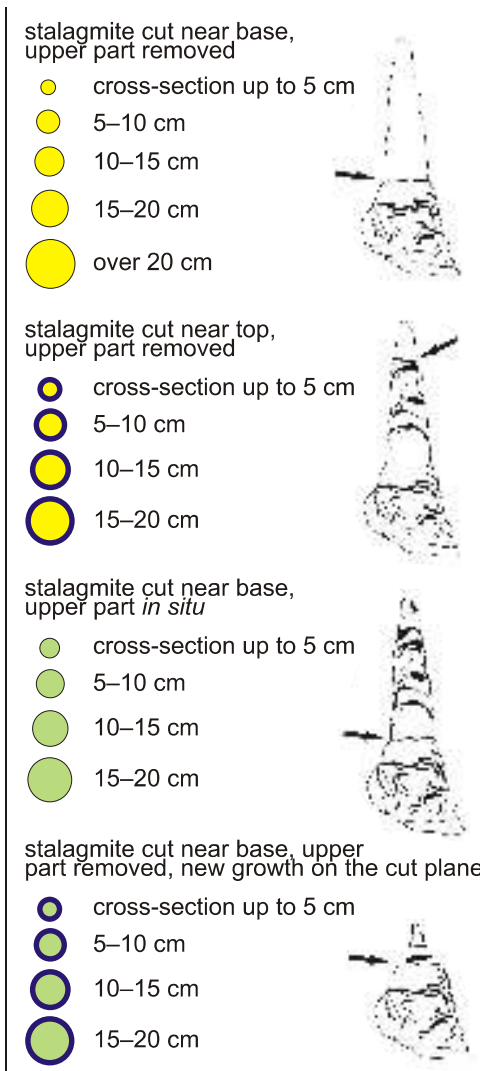

$\Delta$ TM71 gauge (extensometer)

Fig. 4. The Mladeč Cave: map of cave corridors, structural map, location, and styles of speleothem fracturing

to the WNW, with signs of subhorizontal dextral shear (Figs. 2, 5 and 6). The dextral shear is indicated by subhorizontal striations, calcite accretion steps on fault planes (slickensides) and the displacement of flowstones. Another major fault system is trending WNW-ESE with subvertical dips to both $\mathrm{N}$ and S. Minor fault systems are running in W-E, WSW-ENE, and SW-NE directions. A total of 39 steeply dipping faults and 5 thrust faults were found in the Mladeč Cave and in exposures close to the cave entrance (Figs. 3, 5 and 6). Two major fault systems predominate in the Mladeč Cave and its close vicinity (Třesín and Podkova caves), one running in SW-NE to WSW-ENE directions and the other in the NW-SE direction. The former is again associated with subhorizontal dextralshear displacement while the latter is associated with thrusting towards the NE, as indicated by striations and accretion steps on fault planes. The fault systems in Mladeč are very much similar to those in the Javoríčko and JZH Caves, but are dextrally rotated by $\sim 30^{\circ}$. Thrust faults in the Mladeč Cave are often associated with vertical strike-slip faults acting as transfer faults with respect to the thrust faults. In the Tresín and Mladeč caves, the thrust faults are crosscut by younger, normal NW-SE striking faults.

Soft-sediment infill of the caves also shows signs of brittle deformation. A subvertical fault $\left(182^{\circ} / 70^{\circ}\right)$ with subvertical striations $\left(187^{\circ} / 65^{\circ}\right)$ and growth of black manganese oxides on the fault plane was observed in clay sediments in the JZH Cave
(Fig. 7A). Sediment creep and minute normal faults in well-bedded clayey-sandy sediments were observed, in turn, in another corridor of the ZHJ Cave (Fig. 7B), but this deformation is most probably associated with the gravitational collapse of breccia fill in a chimney (cf. Lundberg et al., 2014).

A subvertical NW-SE striking fault with a vertical-displacement component and an offset of about $0.25 \mathrm{~m}$ was recorded in the loessic sediment filling a near-surface, subvertical corridor in the Mladeč Cave (Fig. 7C). One sample from the loessic sediment, located $1 \mathrm{~m}$ above the top of the profile depicted in Figure 7 , was dated using optically-stimulated luminiscence (OSL). The dating yielded an age of $13.12 \mathrm{ka}$ (latest Pleistocene-Early Holocene; Table 2). Two more samples were taken from the sedimentary infill of the fissure (Fig. 7C), yielding 7.95 and $3.31 \mathrm{ka}$ OSL ages (Holocene). The above-mentioned ages (13.12 and $7.95 \mathrm{ka}$ ) give the time constraints for the soft-sediment faulting. However, the loess deposits surrounding the caves are generally older than that, corresponding to Late Weichselian ages (Panoš, 1964). The sediment in the fissure is therefore a secondary accumulation coming from a primary loess source, which was then crosscut by an even younger fault. Another minor subvertical fault with a slight offset was found in the Mladeč Cave. Two charcoal fragments, recovered from the cave floor sediment affected by this fault, yielded calibrated AMS ${ }^{14} \mathrm{C}$ ages $44.9 \pm 0.26 \mathrm{ka}$ and $49.0 \pm 0.27 \mathrm{ka}$ (Weichselian, MIS3; Table 2). 


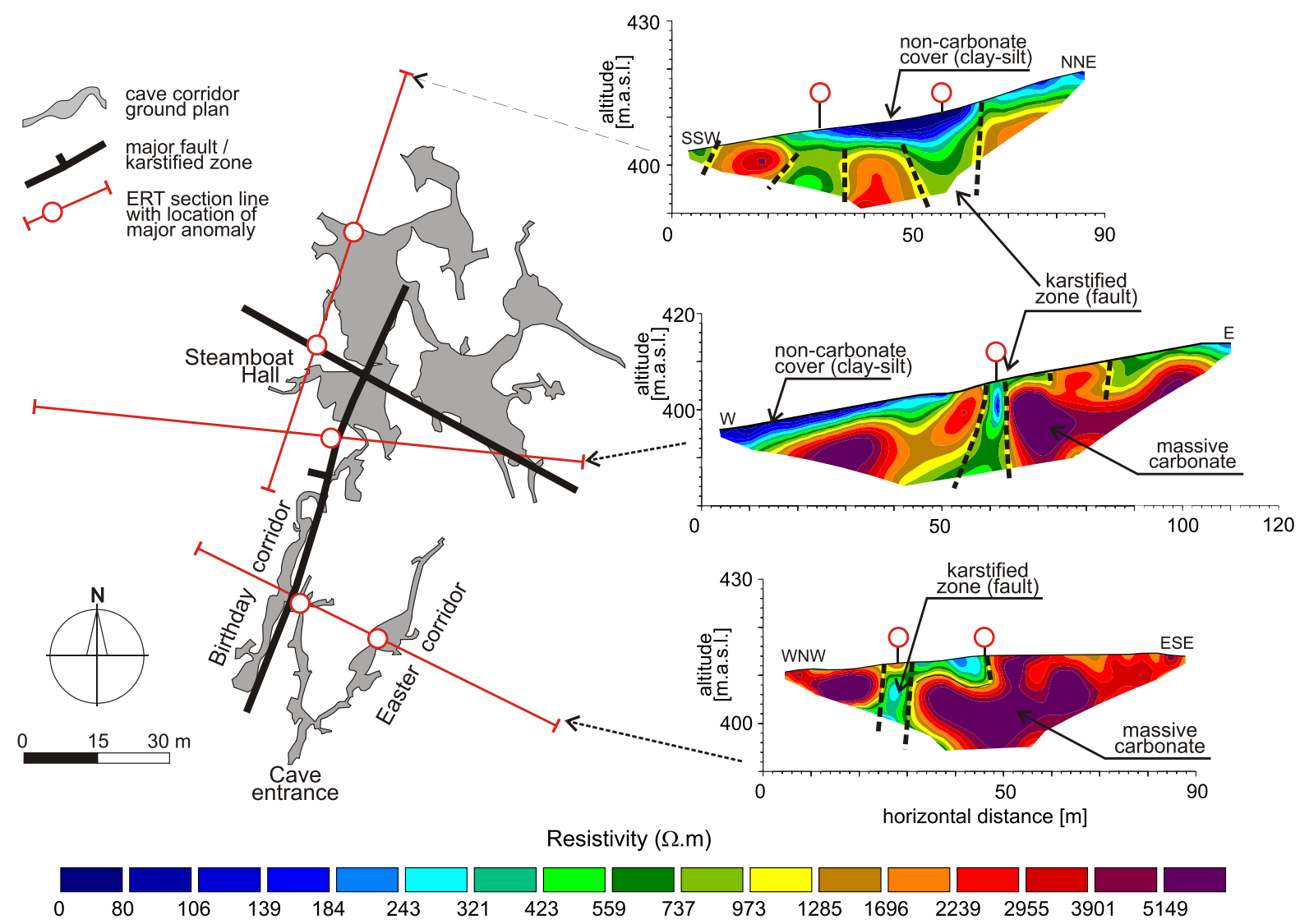

Fig. 5. Electrical resistivity tomography sections measured above the JZH Cave with basic interpretation

Note the subvertical low-resistivity zones (karstified faults), which coincide with the Birthday corridor (NNE-SSW) and its crossing with another, roughly perpendicular fault (WNW-ESE) above the Steamboat Hall

\section{SPELEOTHEM FRACTURING}

Brittle deformation of the speleothems is ubiquitous in all three caves. The relative frequency of speleothem deformation is shown in Figures 3 and 4. The most frequent is the fracturing of soda-straws and thin stalactites on cave ceilings, which was observed in numerous parts of the $\mathrm{JZH}$, Javořičko and Mladeč caves. Massive fracturing of stalactites was observed in Steamboat Hall in the JZH Cave. The cave ceiling at this site is covered by $\sim 50$ to $\sim 200$ thin stalactities and soda-straws per $\mathrm{m}^{2}$, mostly aligned along fractures in the ceiling. All of them are very short and show multi-phase growth. A short (typically 1 to $4 \mathrm{~cm}$ ), relatively thick (typically 1.5 to $3 \mathrm{~cm}$ in diameter) stalactite is overgrown by a thin $(\sim 1 \mathrm{~cm}$ in diameter), short soda-straw, forming a "bottleneck" shape (Fig. 8A, B). The bottom of the cave is covered by hundreds of fallen stalactites, usually less than $10 \mathrm{~cm}$ long. Some of them are lying loose on the floor, but many of them are cemented to the substrate.

The stalactites from the Steamboat Hall in the $\mathrm{JZH}$ (seven polished hand specimens) show several (typically one to four) cycles of fracturing and renewed growth. Dripstone layers in several sampled stalactites show uniform stratigraphic patterns (Fig.

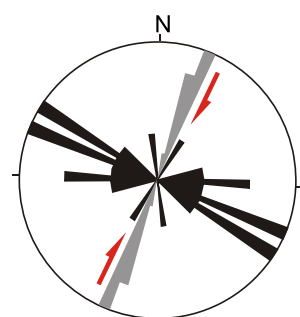

Javoříčko Cave $(n=27)$

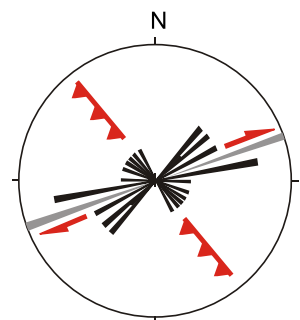

Třesín Cave near Mladeč $(n=25)$

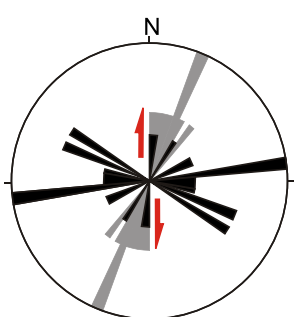

Za hájovnou $(\mathrm{JZ} H)$ Cave

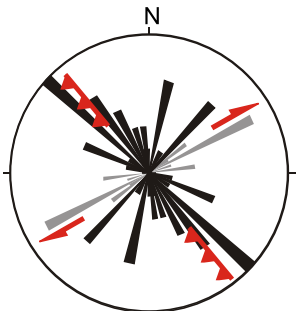

Mladeč Cave $(n=50)$

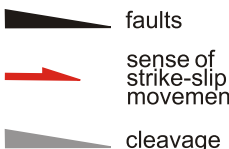

thrusts/ reverse faults

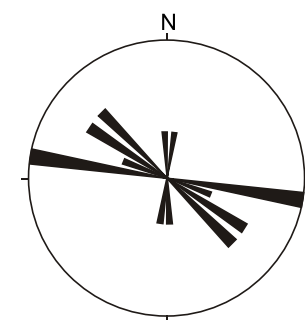

Podkova Cave near Mladeč
Fig. 6. Rose diagrams of major faults from the caves studied

Note the faults inherited from the cleavage (grey) and $\sim 30^{\circ}$ clockwise rotation of the fault systems in the Mladeč Cave as compared the Javoríčč and JZH caves 

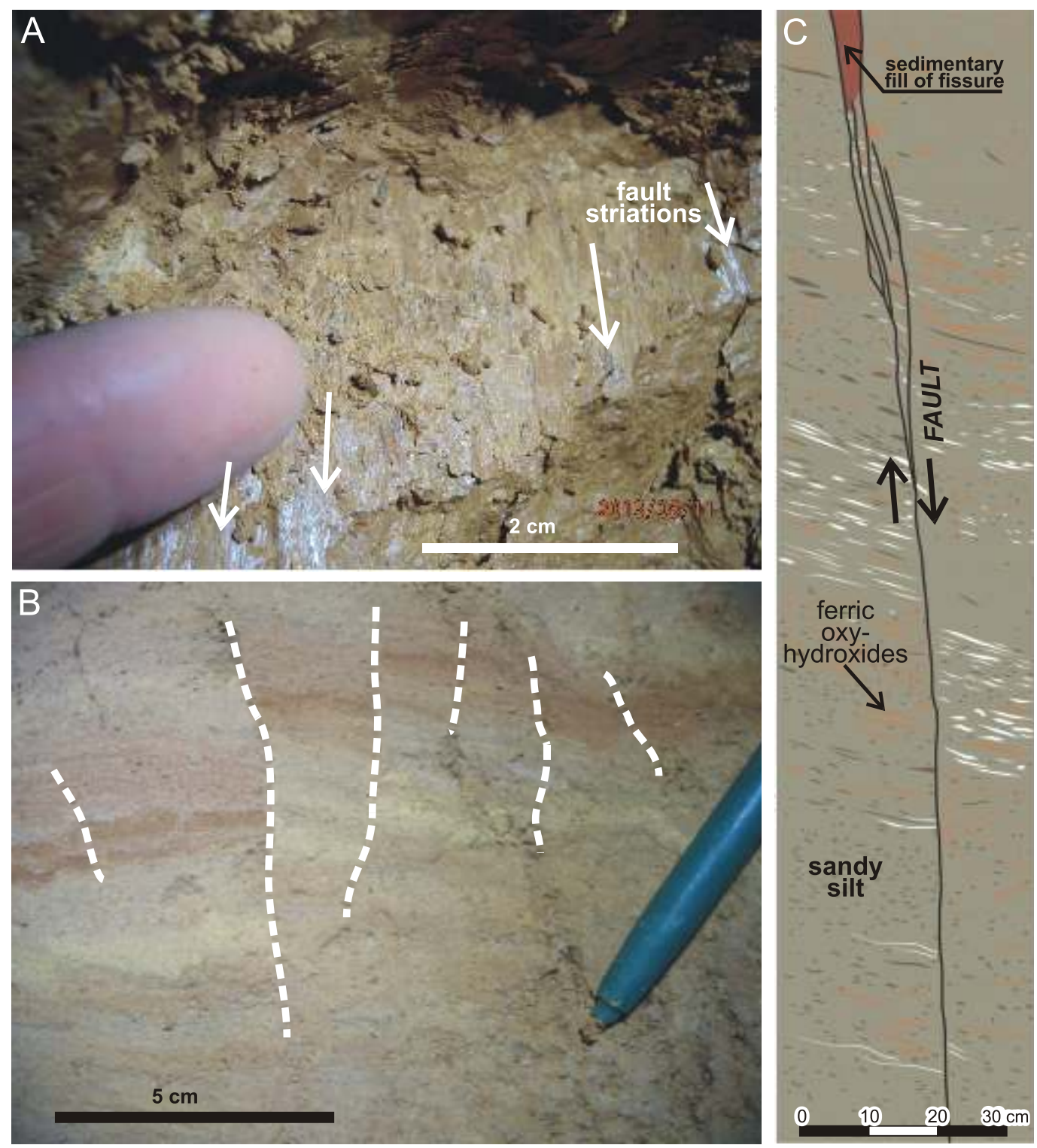

Fig. 7. Brittle deformation of soft cave sediments (see Figs. 3 and 4 for location)

A - exposed fault plane (hanging-wall part sliced off by knife) with Mn oxide-coated striations (arrows), JZH Cave, Plakát's Dream Corridor; B - normal faults in soft sediment, probably associated with gravitational collapse of breccia in karst chimney, JZH Cave, Charnel House; $\mathbf{C}$ - fault offset in loessic sediment filling a subvertical corridor in the Mladeč Cave

8C-E). The youngest layer (1) is typically crystal-white carbonate, followed by a layer (2) of greyish, laminated-carbonate layers (3) and (4) with a distinct banding of white and ochre-coloured sublayers, and a thick layer (5) of brownish carbonate. Each layer is cut by one of the five observed fracture phases (Fig. 8C-E). The most distinct fractures developed during the breakages of layer 2, layer 3, and layer 5 . These patterns of layering and breakage are correlatable across four speleothems and suggest that the fractures occurred as synchronous events.

Another style of speleothem deformation is the fracturing of stalagmites, which was detected in particular in the JZH Cave and Mladeč Cave (Fig. 9). Most common are fractures of stalagmites located in the lower third of their height, while the upper parts of the speleothems are fallen or standing loose on the fracture plane. The cut planes of the former ones are often covered by new-growing stalagmites. Most of the examples of these stalagmites were found standing on subhorizontal or only slightly inclined cave ground. In several instances, the new growth phases are laterally offset with respect to the position of their original growth, indicating that the dripping source on the ceiling shifted. In addition, the fracture planes of some of the cut-and-standing stalagmites were healed by younger dripstone growth. More than 50 such stalagmites were found in the Mladeč Cave (Fig. 4), and several tens in the JZH Cave. Some stalagmites show fracturing in the upper third of their height, but they are not common. Another common feature is the fracturing of flowstone floors, which is ubiquitous in particular in the $\mathrm{JZH}$ Cave. These fractures are locally healed by younger flowstone growth. The syndeformational growth of speleothems is indi- 
Results of U/Th-series dating of broken stalactites, ${ }^{14} \mathrm{C}$ dating of plant material and OSL dating of cave sediments

\begin{tabular}{|c|c|c|c|c|c|c|c|c|}
\hline Sample ID & Lab number & ${ }_{[\mathrm{ng} / \mathrm{g}]}^{238}$ & $\left({ }^{230} \mathrm{Th} /{ }^{232} \mathrm{Th}\right) \mathrm{A}$ & $\left({ }^{230} \mathrm{Th} /{ }^{238} \mathrm{U}\right) \mathrm{A}$ & $\left({ }^{234} U /{ }^{238} U\right) A$ & $\begin{array}{c}\text { Age (corr.) } \\
{[\mathrm{ka}]}\end{array}$ & Error [ka] & $95 \%$ ext. \\
\hline $\mathrm{ZH} 1-1$ & UMD120723-207 & 119 & 47.7 & 0.8274 & 1.2805 & 105.637 & \pm 5.753 & 0.0123 \\
\hline $\mathrm{ZH} 1-2$ & UMD120723-219 & 135 & 266.5 & 1.0412 & 1.0923 & 289.266 & \pm 22.980 & 0.0108 \\
\hline $\mathrm{ZH} 1-3$ & UMD120723-250 & 127 & 121.1 & 0.7616 & 1.0709 & 131.748 & \pm 4.286 & 0.0073 \\
\hline $\mathrm{ZH} 7-1$ & UMD120723-252 & 95 & 53.4 & 0.8253 & 1.7937 & 62.632 & \pm 2.272 & 0.0155 \\
\hline $\mathrm{ZH} 7-3$ & UMD120723-308 & 99 & 39.7 & 1.2213 & 1.4244 & 175.839 & \pm 11.621 & 0.0143 \\
\hline $\mathrm{ZH} 7-4$ & UMD120723-346 & 76 & 9.1 & 1.3516 & 1.3423 & 281.034 & \pm 36.540 & 0.0127 \\
\hline ZH8-1 & UMD120723-366 & 383 & 268.0 & 0.8279 & 0.9420 & 244.775 & \pm 13.261 & 0.0057 \\
\hline ZH8-2 & UMD120723-371 & 148 & 145.3 & 0.7661 & 1.0785 & 131.367 & \pm 4.915 & 0.0064 \\
\hline ZH8-3 & UMD120723-384 & 153 & 642.4 & 0.7490 & 1.0918 & 123.235 & \pm 2.917 & 0.0068 \\
\hline Sample ID & Lab number & Material & $\delta^{13} \mathrm{C}$ & $\begin{array}{l}{ }^{14} \mathrm{C} \text { age, } \\
\text { years } \mathrm{BP}\end{array}$ & & \pm & $\mathrm{pMC}$ & \pm \\
\hline ML2 & UGAMS\# 15812 & wood & -24.2 & 40170 & & 200 & 0.67 & 0.02 \\
\hline ML3 & UGAMS\# 15813 & wood & -26.4 & 45020 & & 280 & 0.37 & 0.02 \\
\hline \multirow[b]{2}{*}{ Sample ID } & \multirow[b]{2}{*}{ Lab number } & \multirow{2}{*}{\multicolumn{2}{|c|}{ Material/grain-size }} & \multicolumn{3}{|c|}{ Activity $[\mathrm{Bq} / \mathrm{kg}]$} & \multirow{2}{*}{$\begin{array}{c}\text { Equivalent } \\
\text { dose [Gy] }\end{array}$} & \multirow{2}{*}{$\begin{array}{l}\text { Age } \\
{[\mathrm{ka}]}\end{array}$} \\
\hline & & & & ${ }^{232} \mathrm{Th}$ & ${ }^{238} U$ & ${ }^{40} \mathrm{~K}$ & & \\
\hline Mladec_1 & GdTL-1825 & \multicolumn{2}{|c|}{ quartz/45-63 $\mu \mathrm{m}$} & 51.56 & 45.06 & 706 & 45.4 & 13.12 \\
\hline Mladec_2 & GdTL-1826 & \multicolumn{2}{|c|}{ quartz/45-63 $\mu \mathrm{m}$} & 52.17 & 40.72 & 631 & 25.7 & 7.95 \\
\hline Mladec_14 & GdTL-1484 & \multicolumn{2}{|c|}{ quartz/125-200 $\mu \mathrm{m}$} & 37.73 & 28.46 & 499 & 10.10 & 3.91 \\
\hline
\end{tabular}

cated by rotated blocks, with multiple growths of stalagmites in several directions. At least two stages of growth and rotation can be documented on a block lying on an inclined $\left(\sim 25^{\circ}\right)$ slope in the corner of the "Steamboat Hall" in JZH Cave (Fig. 9E). In addition, several large boulders are lying on top of old stalagmites, hindering their growth, but these boulders are covered by a new phase of stalagmite growth. This provides another clue as to the syndeformational growth of speleothems.

\section{U/TH DATING OF BROKEN SPELEOTHEMS}

Three stalactites from the JZH showing sequential fracturing and renewed growth were subject to U/Th series dating. The ages range from $62.6 \pm 2.27 \mathrm{ka}$ to $289.3 \pm 23 \mathrm{ka}$ (9 dating points; Table 1). The dating points were selected to represent the succession of broken layers (1) to (5) (Fig. 8). There is a sequence of increasing ages from the surface (layer 2; $62.6 \pm$ $2.27 \mathrm{ka}$ ) to the inner layers (layer $5 ; 281 \pm 36.54 \mathrm{ka}$ ) of the stalactite $\mathrm{ZH} 7$. This age sequence is consistent with the stratigraphy of flowstone layers. However, the other two samples ( $\mathrm{ZH} 1$ and ZH8) failed to show such a "normal" age sequence, while the sample $\mathrm{ZH} 8$ even shows a reversed age sequence, i.e. from the oldest surface layer to the youngest inner layer. The age discrepancies can probably be explained by the mixing of materials from multiple layers during drilling for $\mathrm{U} / \mathrm{Th}$ series dating, while the inner parts of stalactites can be filled with relatively younger carbonate crystallising in their empty inner tubes. The stalactites are very small, and it was difficult to keep the drill in the same layer. At any instance, the ages indicate that the youngest dripstone layers are at least 62.6 ka old and that most of the fracturing is older.

\section{DISCUSSION}

\section{ORIGIN OF SPELEOTHEM FRACTURING}

Since various mechanisms can cause speleothem fracturing, a careful evaluation of its possible origin is required before speleothems can be included in palaeo-earthquake considerations (Forti, 2001). Anthropogenic destruction can be excluded in key parts of the Javoříčko Caves and particularly in the JZH Cave, which were investigated shortly after their discovery in 2011 (cf. Lundberg et al., 2014). Fracturing due to catastrophic floods and the presence of animals can also be excluded, because numerous broken stalagmites are standing upright, and the fallen thin stalactites and soda-straws are still lying where they fell from the ceiling. In addition, although the JZH Cave is known for the presence of cave bear fossils (Lundberg et al., 2014), all the fossil finds come only from the proximal parts of the cave, and no bones of large mammals were found in the more distant parts of the cave involved in this study. Although several quarries were active in the close vicinity of the $\mathrm{JZH}$ and Mladeč caves, fracturing due to the shocks from quarry blasting did not significantly affect the speleothems because most of the stalactite fracturing is dated into the interval from $62.6 \pm 2.27$ to $289.3 \pm 23$ ka (Table 1). Although the Mladeč Cave has been visited by man since Upper Paleolithic times, the presence of broken stalagmites standing upright and faults in the cave sedimentary fill indicates that at least a part of the deformation in this cave is not anthropogenic.

Several arguments for the seismogenic origin of speleothem fracturing can be put forward in the caves studied. First, several sites in the caves show mass fracturing of thin stalac- 

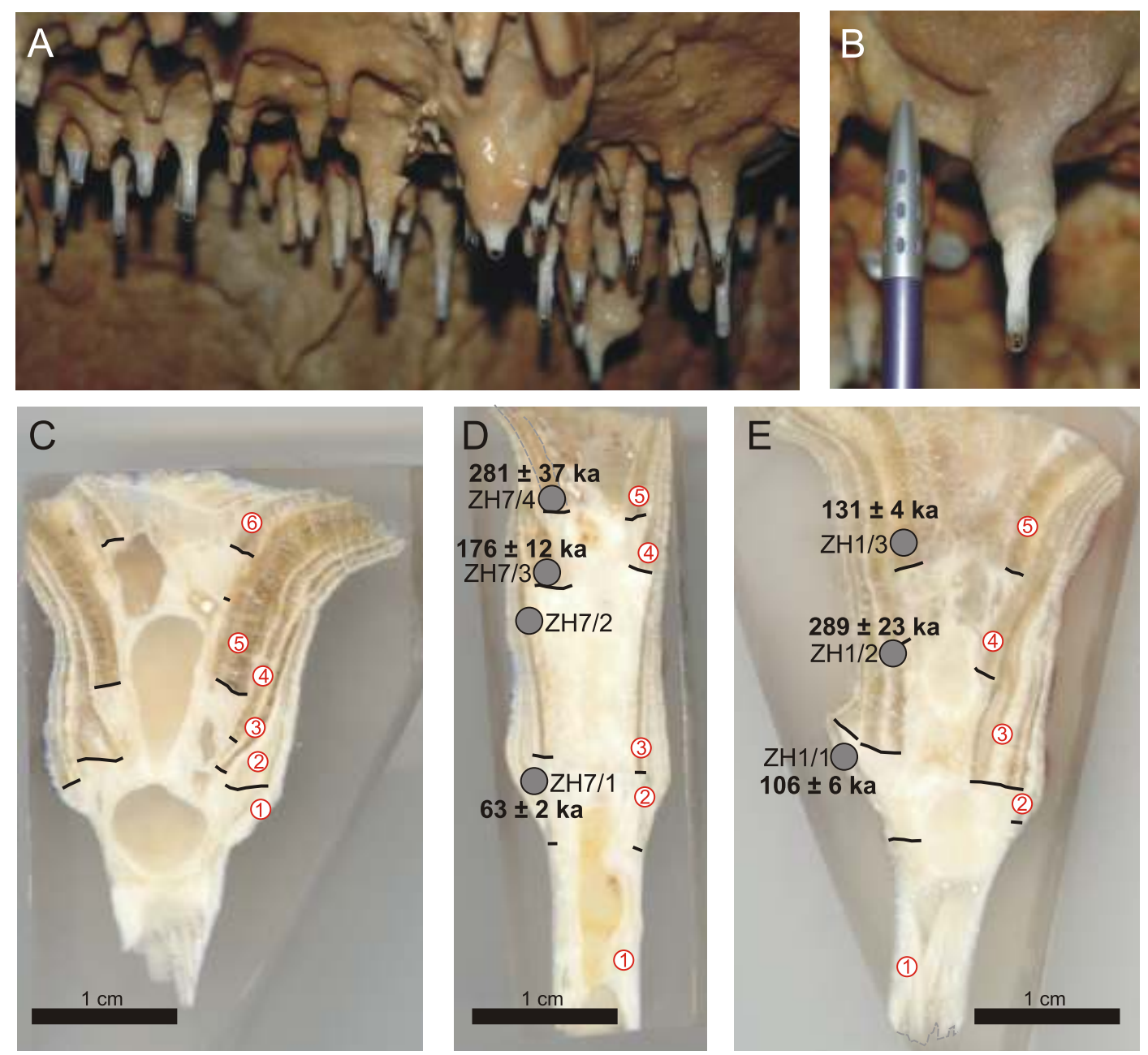

Fig. 8. Stalactite deformation from the JZH Cave

A, B - thin stalactities and soda-straws with "bottleneck" morphology, "Steamboat Hall", JZH; C-E - internal structure of bottleneck stalactites with step-wise fracturing of dripstone layers 1-6 (red circles) and U/Th sampling points (see Table 2)

tites (Steamboat Hall, JZH), leaving the ceiling of the hall covered with hundreds of very short ( 1 to $4 \mathrm{~cm}$ ) broken stalactites. The uniform length of the ceiling stalactites suggests that their fracturing was not gradual but event-like, affecting all the stalactites together, which may suggest a seismic origin (Postpischl et al., 1991). The alternation of the fractures with renewed growth of speleothem layers in stepwise manner, which can be seen on the morphology of hundreds of thin stalactites in all the three cave systems as well as in their internal structure, suggests that the fracturing was periodically repeated. The relative sequence of dripstone layers and their breaking planes, which can be traced in several stalactites (Fig. 8), further indicates that these fracturing events were probably grouped in time. Similar sequences in the fracturing of stalactites were described by Becker et al. (2012) while soda-straw fracturing in general is regarded as a relatively safe indicator of seismic shocks (Gilli et al., 1999; Becker et al., 2006).

Additional information comes from the stalagmites. The basal cut-offs of stalagmites (JZH and Mladeč caves; Fig. 9), with the broken part either lying beside or standing upright on the cut plane with a little translational or rotational shift, suggest that they might have been fractured by seismic shocks (Forti, 2001). Most examples of the standing broken stalagmites were found on subhorizontal cave ground (Steamboat Hall in the JZH Cave), which suggests that their deformation is not related to slope instability or sediment creep. The rotated flowstone blocks, with multiple stalagmite growths in different directions, asymmetric dripstone layering in translated stalagmites, and, most importantly, stalagmites overlain by fallen limestone blocks, provide additional support for tectonic events in the cave (Lameille et al., 1999; Forti, 2001; Delaby, 2001; Gilli, 2005). Moreover, most of the observed cases of speleothem fracturing occur in linear cave corridors, in close association with faults or at the crossing of faults with cleavage (Figs. 3 and 4).

On the contrary, many of the observed features can be considered indicators of cryogenic fracturing in the alternative views of Kempe (2004) and Gilli (2004). Kempe (2004) gives numerous examples of broken-and-standing-upright stalagmites, as well as mass ceiling-stalactite fracturing from the Postojna Jama Cave (Slovenia), and explains them implicitly as 

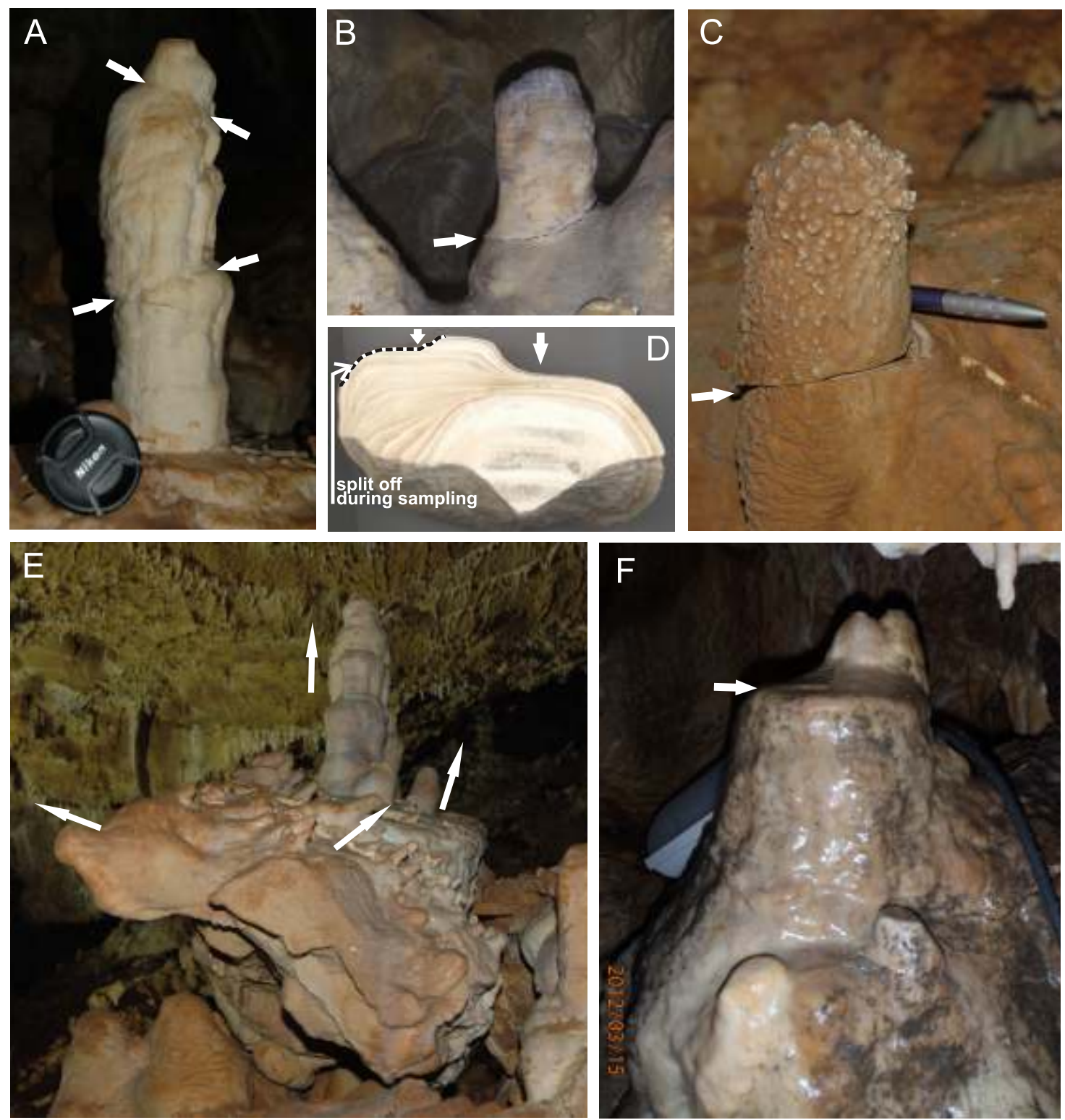

Fig. 9. Different modes of stalagmite deformation from JZH (A, C-E) and Mladeč caves (B, F)

A - fractures healed by new dripstone layers (see arrows); B, C - fresh fracture with cut-off part of stalagmite standing upright (arrows); D - dripping source shift; $\mathbf{E}$ - block rotation with stalagmites growing in four different directions (arrows); F - stalagmite cut-off plane (arrow) healed by new stalagmite growth

cryogenic in origin. However, the same speleothem fracturing from the same cave was interpreted as tectonic in origin in an exhaustive review by Šebela (2008). The depth of ice formation in caves is usually dependent on permafrost depths (Kempe, 2004; Žák et al., 2011) but a steady flow of cold $\left(-10\right.$ to $\left.-15^{\circ}\right)$ air during winter seasons in periglacial areas can cause the freezing of cave floor sediments and flowstone fracturing, even without significant ice formation (Lundberg and McFarlane, 2012). Cryogenic cave carbonates (CCC) have indeed been described from the shallow-subsurface parts $(<30 \mathrm{~m})$ of the Javoříčko Cave (Žák et al., 2011). Their age range (38.09 \pm $0.60 \mathrm{ka}$ and $34.60 \pm 0.41 \mathrm{ka}$ ) corresponds to the Weichselian glaciation (MIS3), which is younger than the age of the JZH speleothem infill (see below). The minimum estimated permafrost depth for the second half of the Weichselian in the western part of the Bohemian Massif is $65 \mathrm{~m}$ (Žák et al., 2011). It is possible that similar permafrost depths can be estimated for the study area implying that cryogenic effects may have taken place in the caves studied.

It is therefore difficult to get unequivocal evidence for tectonic or cryogenic speleothem fracturing in the caves studied solely from the speleothem record, although features such as the upright-standing broken stalagmites and multiphase-breaking of thin stalactites and soda-straws speak for the former interpretation; additional arguments for either of the mechanisms are needed. There is no evidence for cryoturbation, soft-sediment deformation or other structures indicating the presence of ice in the $\mathrm{JZH}$ and Mladeč caves, despite the number of sedimentological, archaeological, palaeontological, and geochemical investigations that have been published from these 
caves (Svoboda et al., 2002; Kadlec et al., 2005; Musil, 2005; Lisá, 2005; Wild et al., 2006; Oliva, 2006; Lundberg et al., 2014). The soft cave sediments of the JZH were recently interpreted as fluvial and colluvial terrestrial sediments (Lundberg et al., 2014). On the other hand, there is evidence of tectonic deformation of the cave soft-sediments, including the slickensides and gravitational collapse in loams of the $\mathrm{JZH}$ and young $(<13.12$ and $7.95 \mathrm{ka}$ ) subvertical faults in the Mladeč caves. Numerous faults on the corridor walls bear frequent calcite slickensides, mostly indicating dextral shear. The fact that the slickensides escaped destruction due to karstification suggests that they postdated the cave-producing process, and that the cave corridors are pre-tectonic or syntectonic in origin. Considering the multiple lines of evidence coming from the different ways of speleothem fracturing, as well as from their local and regional (see below) context, we strongly incline towards a tectonic and not cryogenic origin.

\section{DATING OF FRACTURING EVENTS}

The U/Th dating of the sequence of layers in thin stalactites and soda-straws of the JZH Cave led to controversial results. While in one stalactite, the age sequence is in line with the stratigraphy of dripstone layers, in the other two dated examples it is not. This controversy can perhaps be attributed to a mixing of the layers' material during sampling of the thin layers on very small stalactites and the crystallisation of young carbonate in their inner tubes. However, the age range $62.6 \pm$ $2.27 \mathrm{ka}$ to $289.3 \pm 23 \mathrm{ka}$ corresponds to the range of the flowstone ages in the same cave (Lundberg et al., 2014). Three profiles excavated by these authors in the bottom sediments of the cave revealed a distinct layer of fossiliferous breccia, with numerous bones and limestone boulders, which is sealed by an undeformed flowstone layer. The age of the main fossiliferous bed is Holsteinian sensu lato (MIS9). Deeper layers from the profiles revealed even older fossils, which correspond to MIS11, while the oldest fluvial sediments from the cave are palaeomagnetically dated to the Brunhes/Matuyama boundary (Kadlec et al., 2005). Flowstone clasts from the breccia and the overlying flowstone layer yielded ages from $118 \pm 1 \mathrm{ka}$ to $267 \pm 3 \mathrm{ka}$ (Lundberg et al., 2014). Consequently, the U/Th ages from the stalactites, which are synchronous with the youngest-known sedimentary fill from the JZH Cave, suggest that the last important period of fracturing terminated approximately in the Late Saalian to mid-Weichselian stage (MIS6 to MIS5; cf. Lundberg et al., 2014). Several studies suggested that conditions were favourable for speleothem growth in Central European caves during the MIS 5 and 6 stages (Hercman et al., 2008; Gradziński et al., 2012). This provides an additional argument against the presence of permafrost and the cryogenic origin of the speleothem fracturing in our caves. No U/Th speleothem data are available from the Mladeč and Javoŕícko caves, because these caves are protected areas. Radiocarbon dating from human remains and carbonates from the Mladeč Cave indicates an age range from 45 to $30 \mathrm{ka}$ (MIS3) (Neruda and Nerudová, 2013). However, the OSL and radiocarbon dates of soft sediment from the Mladeč Cave affected by faulting suggest that the brittle deformation events were no older than the Weichselian (MIS3) or even Early Holocene (between 7.95 to $13.12 \mathrm{ka})$.

\section{REGIONAL TECTONIC CONTEXT OF THE SPELEOTHEM FRACTURING: THE UPPER MORAVA BASIN}

Those cave systems studied that show evidence of seismogenic fracturing are located on the flanks of the Upper Morava Basin, a syntectonic basin located within the seismically active Nysa Morava Zone (Špaček et al., 2015). Several seismic events with a maximum magnitude of $\mathrm{M}_{\mathrm{w}} \approx 4.9\left[\mathrm{I}_{\mathrm{EMS}}=\right.$ 7] have occurred in the NMZ since the 16th century. More historical events, ranging from $\mathrm{I}_{0}=4-7 \mathrm{MKS}$, are known from the Sudetic Marginal Fault at the NW margin of the NMZ (Guterch and Lewandowska-Marciniak, 2002). No data about pre-historical earthquakes are available from the Upper Morava Basin and its vicinity, but Pleistocene to Holocene events with a maximum moment magnitude of $M 6.3$ have been inferred from trenching studies of the Sudetic Marginal Fault (Štěpančíková et al., 2010). The distinct topography of the fault is related to its palaeoseismic activity, with the magnitude of individual palaeoearthquakes exceeding $M=5$ (cf. McCalpin, 2009; Stěpančíková et al., 2010). The present-day seismicity in the $\mathrm{NMZ}$ is indicated by numerous small (maximum $\mathrm{M}_{\mathrm{L}} \approx$ 3.8) events, the epicentres of which tend to be aligned with NW-SE trending regional faults, the Nectava-Konice-Kvasice Fault system (NKFS), Temenice Fault (TF), and Bělá Fault (BF) (Fig. 1). The NMZ is explained as a transfer zone developed between the WNW-ESE trending faults (NKFS, TF, BF, and other faults in extension of the upper Elbe Fault System) and NW-SE trending faults active in a dextral transpressional setting (Špaček et al., 2015). Fault plane solutions from several low-magnitude events indicate that the NMZ region is governed by present-day subhorizontal NW-SE compression $(\sigma 1-\sigma 2)$ combined with NE-SW extension $(\sigma 3)$ (Fig. 1). The present-day regional stress fields at the Bohemian Massif Western Carpathians junction are largely controlled by the continuing convergence between the Adria and European Platform, combined with ridge-push originating at the Mid-Atlantic rift system (Ziegler and Dézes, 2007; Jarosiński et al., 2009). The local stress fields were highly variable in space and time from Miocene to present-day times (Marko et al., 1995; Peresson and Decker, 1997; Ziegler and Dézes, 2007; Pešková et al., 2009). In addition, the local stress fields in the northern Bohemian Massif during the Quaternary were strongly affected by far-field effects of the Elsterian and Saalian continental ice-sheets (cf. Nývlt et al., 2011).

The transfer of the regional stress field into the network of faults within the NMZ (Fig. 10) results in local extensional to transtensional regimes (Špaček et al., 2015). The cave corridors studied are governed by a network of WNW-ESE to NW-SE trending faults and NNE-SSW to NE-SW trending cleavage. The former set of faults corresponds to the seismically active faults of the NMZ, in particular the Temenice Fault and the Nectava-Konice-Kvasice Fault, which represent the eastern extension of the upper Elbe Fault System. The latter set of faults is inherited from the Variscan ductile and brittle deformation of the Paleozoic carbonates, which host the cave systems (Bábek et al., 2006). This tectonic fabric controls the morphology of all the three caves, while seismic events related to the upper Elbe Fault System may have been responsible for the observed speleothem fracturing. The dextral shear, indicated by slickensides on NNE-SSW trending faults in the Javořičko and JZH caves, does not correspond to the present-day stress field (NNW- to NW-oriented maximum horizontal stress, 


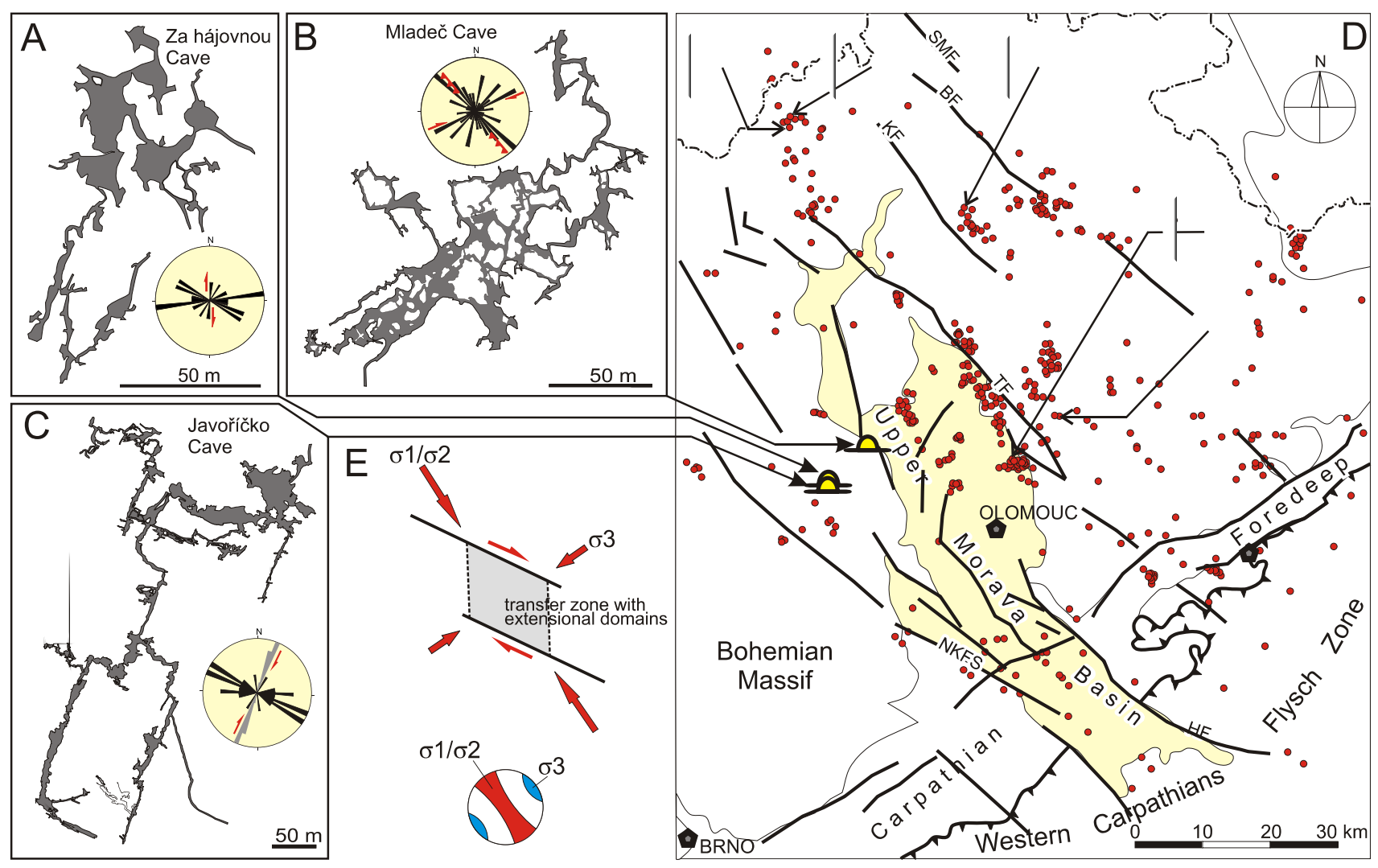

Fig. 10. Synoptic diagram of tectonic context of the speleothem fracturing in the JZH, Javoříčko and Mladeč caves

A-C - maps of cave corridors and rose diagrams (see Fig. 5); D - tectonic sketch of the Upper Morava Basin and its vicinity with major regional-scale faults indicated, earthquake epicentres and fault-plane solutions of selected seismic events; $\mathbf{E}-$ model of NMZ as an extensional transfer zone (relay ramp) between two terminations of non-coalescing WNW-ENE to NW-SE strike-slip faults (adopted from Špaček et al., 2015)

Špaček et al., 2015), as indicated by the fault plane solutions from seismic events (Fig. 10). In the Mladeč Cave, the palaeostress field is more similar to the regional present-day stress. This suggests that the palaeostress may have varied considerably both in space and time.

Because none of the studied caves are cross-cut by a seismically active major fault (cf. Šebela, 2008), it can be speculated whether local seismic events, related to gravitational collapse or local fault movements, or a wavefront passage, derived from a strong and distant seismic event, caused the observed speleothem fracturing (cf. Pons-Branchu et al., 2004).

\section{TECTONIC SPELEOTHEM FRACTURING} IN THE WESTERN CARPATHIANS FORELAND

Studies describing speleothem fracturing related to past seismic events are not common in Central Europe. Three caves were studied in the northern and eastern parts of the Bohemian Massif, the Západní Cave, Na Pomezí Cave, and Na Špičáku Cave (Stemberk et al., 2010; Briestenský et al., 2014a), and one, the Driny Cave, in the Western Carpathians (Briestenský et al., 2011). The former three are situated close to the upper Elbe Fault Zone and the Sudetic Marginal Fault. A tectonic origin of speleothem fracturing in these case studies is supported by accompanying data from fault-displacement monitoring using extensometers. The authors cited suggest that subsurface monitoring is much less sensitive to climatic effects, and therefore more appropriate for fault-displacement than surface monitoring (Briestenský et al., 2014a). Apart from local events, cave systems sensitively respond to global seismic events with vigorous fluctuation of $\mathrm{CO}_{2}$ and radon fluxes (Heinicke et al., 1995). Two caves of the Nysa Morava Zone, the Mladeč Cave and the Zbrašov Cave, showed increased fluxes of radon and $\mathrm{CO}_{2}$, as well as accelerated fault movements during the Tohoku earthquake $\left(\mathrm{M}_{\mathrm{W}}=9.0\right)$ from March, 2011 (Briestenský et al., 2014b). This combined evidence suggests that caves at the northeastern margin of the Bohemian Massif are sensitive indicators of Quaternary tectonic deformation, related, presumably, to the convergence between the Western Carpathians and their foreland.

\section{CONCLUSIONS}

Three cave systems, situated in the eastern Bohemian Massif, the JZH Cave, Javoříčko Cave, and Mladeč Cave, near the Carpathian orogenic front, provide evidence of the repeated 
fracturing of stalagmites and stalactites. The origin of speleothem fracturing is discussed and finally interpreted as seismogenic, based on multiple pieces of evidence coming from the speleothems themselves, from the deformation of clastic cave sediments and from the morphology and structure of the cave systems.

$\mathrm{U} / \mathrm{Th}$ series dating of broken stalactites form the JZH Cave indicate that the last fracturing event occurred in the Late Pleistocene (MIS6 to MIS5). These U/Th ages are in accord with previous $\mathrm{U} / \mathrm{Th}$ dates from brecciated flowstone layers (Lundberg et al., 2014). However, OSL dating of faulted sedimentary infill may even indicate latest Pleistocene to Early Holocene tectonic events to occur in the Mladeč Cave.

The timings of seismogenic speleothem-fracturing are discussed in the regional context of the Nysa-Morava Zone, a present-day tectonically-active domain at the junction between the Bohemian Massif and the Western Carpathians. The caves studied provide the first evidence of palaeoearthquake events in this zone, which otherwise shows present-day seismicity and numerous indirect pieces of evidence of Late Cenozoic tectonic activity.

Acknowledgments. This study was supported by the Czech Science Foundation (GAČR) project P210/12/0573. The paper benefied from very helpful and constructive reviews by S. Šebela (Ljubljana), M. Gradziński (Kraków), and P. Aleksandrowski (Wrocław). The authors thank numerous cavers from the local caving clubs "7-09 Estavela" and "7-03 Javoříčko", and the Cave Administration of the Czech Republic for their help with fieldwork.

\section{REFERENCES}

Aleksandrowski, P.. 1995. Role of large-scale strike-slipe movements for the Variscan structure of Sudetes Mts (SW Poland) (in Polish with English summary). Przegląd Geologiczny, 43: 745-754.

Audemard, M.F.A., Michetti, A.M., 2011. Geological criteria for evaluating seismicity revisited: forty years of paleoseismic investigations and the natural record of past earthquakes. GSA Special Papers, 479: 1-21.

Bábek, O., Mikuláš, R., Zapletal, J., Lehotský, T., 2004. Combined tectonic-sediment supply-driven cycles in a Lower Carboniferous deep-marine foreland basin, Moravice Formation, Czech Republic. International Journal of Earth Sciences, 93: 241-261.

Bábek, O., Tomek, Č., Melichar, R., Kalvoda, J., Otava, J., 2006. Structure of unmetamorphosed Variscan tectonic units of the southern Moravo-Silesian zone, Bohemian Massif: a review. Neues Jahrbuch für Geologie und Paläontologie Abhandlungen, 239: 37-75.

Bábek, O., Přikryl, T., Hladil, J., 2007. Progressive drowning of carbonate platform in the Moravo-Silesian Basin (Czech Republic) before the Frasnian/Famennian event: facies, compositional variations and gamma-ray spectrometry. Facies, 53: 293-316.

Becker, A., Davenport, C.A., Eichenberger, U., Gilli, E., Jeannin, P.Y., Lacave, C., 2006. Speleoseismology: a critical perspective. Journal of Seismology, 10: 371-388.

Becker, A., Häuselmann, P., Eikenberg, J., Gilli, E., 2012. Active tectonics and earthquake destructions in caves of northern and central Switzerland. International Journal of Speleology, $\mathbf{4 1}$ 35-49.

Briestenský, M., Košt'ák, B., Stemberk, J., Petro, L., Vozár, J., Fojtíková, L., 2010. Active tectonic fault microdisplacement analyses: a comparison of results from surface and underground monitoring in western Slovakia. Acta Geodynamica et Geomaterialia, 7: 387-397. $\mathrm{t}^{\prime}$

Briestenský, M., Stemberk, J., Michalík, J., Bella, P., Rowberry, M.D., 2011. The use of a karstic cave system in a study of active tectonics: fault movements recorded at Driny Cave, Malé Karpaty Mts (Slovakia). Journal of Cave and Karst Studies, 73 : 114-123.

Briestensky, M., Stemberk, J., Rowberry, M.D., 2014a. The use of damaged speleothems and in situ fault displacement monitoring to characterise active tectonic structures: an example from Zapadni cave, Czech Republic. Acta Carsologica, 43: 129-138.

Briestenský, M., Thinová, L., Praksová, R., Stemberk, J., Rowberry, M.D., Knejflová, Z., 2014b. Radon, carbon dioxide, and fault displacements in central Europe related to the Tōhoku
Earthquake. Radiation Protection Dosimetry, doi:10.1093/rpd/ncu090

Crispim, J.A., 1999. Seismotectonic versus man-induced morphological changes in a cave on the Arrabida chain (Portugal). Geodinamica Acta, 12: 135-142.

Delaby, S., 2001. Palaeoseismic investigations in Belgian caves. Netherlands Journal of Geosciences/Geologie en Mijnbouw, 80: 323-332.

Dézes, P., Schmid, S., Ziegler, P.A., 2004. Evolution of the European Cenozoic Rift System: interaction of the Alpine and Pyrenean orogens with their foreland lithosphere. Tectonophysics, 389: 1-33.

Fairbanks, R.G., Mortlock, R.A., Chiu, T.C., Cao, L., Kaplan, A. Guilderson, T.P., Fairbanks, T.W., Bloom, A.L., 2005. Marine radiocarbon calibration curve spanning 0 to 50,000 years B.P. based on paired ${ }^{230} \mathrm{Th} /{ }^{234} \mathrm{U} /{ }^{238} \mathrm{U}$ and ${ }^{14} \mathrm{C}$ dates on pristine Corals. Quaternary Science Reviews, 24: 1781-1796.

Forti, P., 2001. Seismotectonic and paleoseismic studies from speleothems: the state of the art. Geologica Belgica, 4: 175-185.

Franke, W., elaźniewicz, A., 2000. The eastern termination of the Variscides: terrane correlation and kinematic evolution. Geological Society Special Publications, 179: 63-86.

Frumkin, A., Karkanas, P., Bar-Matthews, M., Barkai, R., Gopher, A., Shahack-Gross, R., Vaks, A., 2009. Gravitational deformations and fillings of aging caves: the example of Qesem karst system, Israel. Geomorphology, 106: 154-164.

Gilli, E., 1999. Breaking of speleothems by creeping of a karstic filling. The example of the Ribiere cave (Bouches-du-Rhone). Comptes Rendus de l'Academie des Sciences Serie II Fascicule A-Sciences de la Terre et des Planetes, 329: 807-813.

Gilli, E., 2004. Glacial causes of damage in caves and difficulties to use speleothems as seismic or neotectonic indicators. Geodinamica Acta, 17: 229-240.

Gilli, E., 2005. Review on the use of natural cave speleothems as palaeoseismic or neotectonics indicators. Comptes Rendus Geosciences, 337: 1208-1215.

Gilli, E., Levret, A., Sollogoub, P., Delange, P., 1999. Research on the February 18, 1996 earthquake in the caves of Saint-Paulde-Fenouillet area, (eastern Pyrenees, France). Geodinamica Acta, 12: 143-158.

Gradziński, M., Dulinski, M., Hercman, H., 2012. Peculiar calcite speleothems filling fissures in calcareous sandstones and their palaeohydrological and palaeoclimatic significance: an example from the Polish Carpathians. Geological Quarterly, 56 (4): 711-732. 
Grygar, R., Jelínek, J., 2003. The Upper Morava and Nysa pullapart grabens - the evidence of neotectonic dextral transtension on the sudetic fault system. Acta Montana, A 24: 51-59.

Grygar, R., Vavro, M., 1995. Evolution of Lugosilesian Orocline (North-eastern periphery of the Bohemian Massif): kinematics of Variscan deformation. Journal of Czech Geological Society, 40: 65-90.

Guterch, B., Lewandowska-Marciniak, H., 2002. Seismicity and seismic hazard in Poland. Folia Quaternaria, 73: 85-99.

Hartley, A.J., Otava, J., 2001. Sediment provenance and dispersa in a deep marine foreland basin: the Lower Carboniferous Culm Basin, Czech Republic. Journal of the Geological Society, 158: 137-150.

Heinicke, J., Koch, U., Martinelli, G., 1995. $\mathrm{CO}_{2}$ and radon measurements in the Vogtland Area (Germany) - a contribution to earthquake prediction research. Geophysical Research Letters, 22: $771-774$.

Hellstrom, J., 2003. Rapid and accurate U/Th dating using paralle ion-counting multi-collector ICP-MS. Journal of Analytica Atomic Spectrometry, 18: 1346-1351.

Hellstrom, J., 2006. U-Th dating of speleotherns with high initia Th-230 using stratigraphical constraint. Quaternary Geochronology, 1: 289-295.

Hercman, H., Gradzinski, M., Bella, P., 2008. Evolution of Brestovská Cave based on U-series dating of speleothems. Geochronometria, 32: 1-12.

Jarosiński, M., Poprawa, P., Ziegler, P.A., 2009. Cenozoic dynamic evolution of the Polish Platform. Geological Quarterly, $\mathbf{5 3}$ (1): 3-26

Kadlec, J., Chadima, M., Pruner, P., Schnabl, P., 2005. Paleomagnetické datování sedimentů v jeskyni „Za Hájovnou” v Javoříčku - předběžné výsledky (in Czech). Prrírodovědné studie Muzea Prostějovska, 8: 75-82.

Kagan, E.J., Agnon, A., Bar-Matthews, M., Ayalon, A., 2005. Dating large infrequent earthquakes by damaged cave deposits. Geology, 33: 261-264.

Kalvoda, J., Bábek, O., Fatka, O., Leichmann, J., Melichar, R., Nehyba, S., Špaček, P., 2008. Brunovistulian terrane (Bohemian Massif, Central Europe) from late Proterozoic to late Paleozoic: a review. International Journal of Earth Sciences, 97 497-518.

Kashima, N., 1993. Fracture of speleothems in Hoshino-no-ana Cave, Minami-Daito Island, Okinawa Prefecture, Southwest Japan. Journal of the Speleological Society of Japan, 18: 33-41.

Kempe, S., 2004. Natural speleothem damage in Postojnska jama (Slovenia), caused by glacial cave ice? A first assessment. Acta Carsologica, 33: 265-289.

Lemeille, F., Cushing, M., Carbon, D., Grellet, B., Bitterli, T., Flehoc, C., Innocent, C., 1999. Co-seismic ruptures and deformations recorded by speleothems in the epicentral zone of the Basel earthquake. Geodinamica Acta, 12: 179-191.

Lisá, L., 2005. Sedimentologie a stratigrafie sedimentů Komínu I ve vchodu jeskyně „Za Hájovnou“, Javoříčský kras (in Czech). Prírodovědné studie Muzea Prostějovska, 8: 43-48.

Lundberg, J., McFarlane, D., 2012. Cryogenic fracturing of calcite flowstone in caves: theoretical considerations and field observations in Kents Cavern, Devon, UK. International Journal of Speleology, 41: 307-316.

Lundberg, J., Musil, R., Sabol, M., 2014. Sedimentary history of Za Hájovnou cave (Moravia, Czech Republic): A unique Middle Pleistocene palaeontological site. Quaternary International, 339-340: 11-24.

Marko, F., Plašienka, D., Fodor, L., 1995. Meso-Cenozoic stress field within the Alpine-Carpathian transition zone: a review. Geologica Carpathica, 46: 19-27.

Mazur, S., Aleksandrowski, P., Kryza, R., Oberc-Dziedzic, T., 2006. The Variscan Orogen in Poland. Geological Quarterly, 50 (1): 89-118

McCalpin, J. ed., 2009. Paleoseismology. Academic Press.

Morinaga, H., Yonezawa, T., Adachi, Y., Inokuchi, H., Goto, H., Yaskawa, K., 1994. The possibility of inferring paleoseismicity from paleomagnetic dating of speleothems, Western Japan. Tectonophysics, 230: 241-248.

Musil, R., 2005. Jeskyně Za hájovnou, vyjímečná lokalita Javořičský kras, Morava. Př́rodovědné studie Muzea Prostějovska, 8: 11-39

Neruda, P., Nerudová, Z., 2013. The Middle-Upper palaeolithic transition in Moravia in the context of the Middle Danube region. Quaternary International, 294: 3-19.

Nývlt, D., Engel, Z., Tyráček, J., 2011. Pleistocene glaciations of Czechia. Developments in Quaternary Science, 15: 37-46.

Oliva, M., 2006. The Upper Paleolithic finds from the Mladeč Cave. In: The Mladeč Caves and their Remains: Early Modern Humans at the Moravian Gate (ed. M. Teschler-Nicola): 41-74. Springer, Wien, New York

Otava, J., Morávek, R., 2013. Excursion Guide B3CZ, A3CZ The Most Interesting Karstological Phenomena of Moravia. 16th International Congress of Speleology, July 21-28. Brno. Excursion Guide B3CZ, A3CZ. 32 s. - Czech Speleological Society, Praha, Czech Republic.

Panno, S.V., Lundstrom, C.C., Hackley, K.C., Curry, B.B., Fouke, B.W., Zhang, Z., 2009. Major earthquakes recorded by speleothems in Midwestern U.S. caves. Bulletin of the Seismological Society of America, 99: 2147-2154

Panoš, V., 1964. Der Urkarst im Ostflügel der Böhmische Masse. Beitrag zur Lösung allgemainer Entwicklungsfragen des Karstes in verschiedenen Klimazonen. Zeitschrift der Geomorphologie, 8: 105-162

Peresson, H., Decker, K., 1997. The Tertiary dynamics of the Northern Eastern Alps (Austria): changing paleostresses in a collisional plate boundary. Tectonophysics, 272: 125-157.

Pešková, I., Vojtko, R., Starek, D., Sliva, L., 2009. Late Eocene to Quaternary deformation and stress field evolution of the Orava region (Western Carpathians). Acta Geologica Polonica, 59: 73-91.

Pícha, F.J., Stráník, Z., Krejčí, O., 2006. Geology and hydrocarbon resources of the Outer Western Carpathians and their foreland, Czech Republic. AAPG Memoir, 84: 11-46.

Plan, L., Grasemann, B., Spötl, C., Decker, K., Boch, R., Kramers, J., 2010. Neotectonic extrusion of the Eastern Alps: constraints from U/Th dating of tectonically damaged speleothems. Geology, 38: 483-486.

Pons-Branchu, E., Hamelin, B., Brulhet, J., Bruxelles, L., 2004. Speleothem rupture in karst: tectonic or climatic origin? U-Th dating of rupture events in Salamandre Cave (Gard, southeastern France). Bulletin de la Societe Geologique de France, 175: 473-479.

Postpischl, D., Agostini, S., Forti, P., Quinf, Y., 1991. Paleoseismicity from karst sediments - the Grotta-del-Cervo cave case-study (central Italy). Tectonophysics, 193: 33-44.

ProdehI, C., Mueller, S., Haak, V., 1995. The European Cenozoic Rift system. Developments in Geotectonics, 25: 33-212.

Rajlich, P., 1990. Variscan shearing tectonics in the Bohemian Massif. Mineralia Slovaca, 22: 33-40.

Růžička, M., 1973. Fluviatile sediments of the Morava river around Olomouc (in Czech with English summary). Journal of Geological Science (Anthropozoic), 9: 7-38.

Scheck, M., Bayer, U., Otto, V., Lamarche, J., Banka, D., Pharaoh, T., 2002. The Elbe Fault System in North Central Europea basement controlled zone of crustal weakness. Tectonophysics, 360: 281-299.

Schulmann, K., Gayer, R., 2000. A model for a continental accretionary wedge developed by oblique collision: the NE Bohemian Massif. Journal of the Geological Society, 157: 401-416.

Stemberk, J., Košt’ák, B., Cacon, S., 2010. A tectonic pressure pulse and increased geodynamic activity recorded from the long-term monitoring of faults in Europe. Tectonophysics, 487 $1-12$

Stráník, Z., Dvořák, J., Krejčí, O., Müller, P., Přichystal, A., Suk, M., Tomek, Č., 1993. The contact of the North European Epivariscan platform with the West Carpathians. Journal of the Czech Geological Society, 38: 21-30. 
Svoboda, J., Havlíček, P., Ložek, V., Macoun, J., Musil, R., Přichystal, A., Svobodová, H., Vlček, E., 2002. Paleolit Moravy a Slezska (in Czech). Dolnověstonické studie, svazek 8. Archeologický ústav AVČR Brno.

Šebela, S., 2008. Broken speleothems as indicators of tectonic movements. Acta Carsologica, 37: 51-62.

Špaček, P., Zacherle, P., Sýkorová, Z., Pazdírková, J., 2011. Microseismic multiplets in the northeastern Bohemian Massif. Zeitschrift der Geologische Wissenschaften, 39: 367-386.

Špaček, P., Bábek, O., Štěpančíková, P., Švancara, J., Pazdírková, J., Sedláček, J., 2015. The Nysa Morava Zone: an active tectonic domain with Late Cenozoic sedimentary grabens in the Western Carpathians' foreland (NE Bohemian Massif). International Journal of Earth Sciences, doi 10.1007/s00531014-1121-7

Štěpančíková, P., Hók, J., Nývlt, D., Dohnal, J., Sýkorová, I., Stemberk, J., 2010. Active tectonics research using trenching technique on the south-eastern section of the Sudetic Marginal Fault (NE Bohemian Massif, central Europe). Tectonophysics, 485: 269-282.

Ulrych, J., Ackerman, L., Balogh, K., Hegner, E., Jelínek, E., Pécskay, Z., Přichystal, A., Upton, B.G.J., Zimák, J., Foltýnová, R., 2013. Plio-Pleistocene basanitic and melilititic series of the Bohemian Massif: $\mathrm{K}-\mathrm{Ar}$ ages, major/trace element and $\mathrm{Sr}-\mathrm{Nd}$ isotopic data. Chemie der Erde, 73: 429-450.

Widera, M., Haluszczak, A., 2011. Stages of the Cenozoic tectonics in central Poland: examples from selected grabens. Zeitschrift der Deutsches Gesellschaft der Geowissenschaften, 162: 203-215.

Wild, E.M., Teschler-Nicola, M., Kutschera, W., Steier, P., Wanek, W., 2006. ${ }^{14} \mathrm{C}$ dating of Early Upper Palaeolithic human and faunal remains from Mladeč. In: Early Modern Humans at the Moravian Gate: the Mladeč Caves and their Remains (ed. M. Teschler-Nicola): 149-158. Springer, Wien, New York.

Wilson, M., Downes, H., 2006. Tertiary-Quaternary intra-plate magmatism in Europe and its relationship to mantle dynamics. Geological Society Memoirs, 32: 147-166.

Ziegler, P.A., Dézes, P., 2007. Cenozoic uplift of Variscan Massifs in the Alpine foreland: Timing and controlling mechanisms. Global and Planetary Change, 58: 237-269.

Žák, K., Richter, D.K., Filippi, M., Živor, R., Deininger, M., Mangini, A., Scholz, D., 2011. Cryogenic cave carbonate - a new tool for estimation of the Last Glacial permafrost depth of the Central Europe. Climate of the Past Discussions, 8: 2145-2185. 